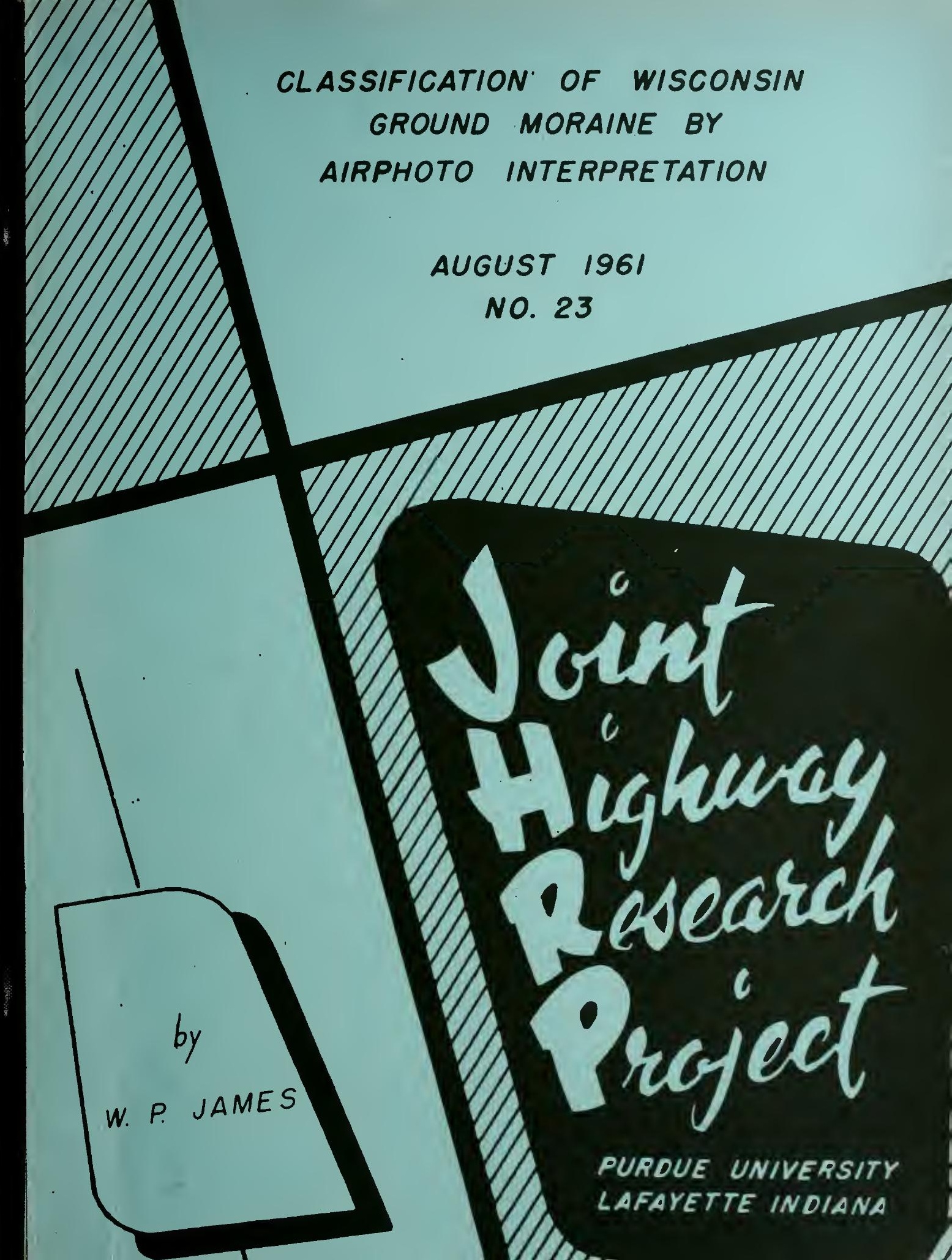





\section{Fine] Report}

\section{CLASSIFICATION OF WISCONSIN GPOUND MORIITE EI \\ ATPPHOTO INTERPDETATION}

TO: Ko Ba Woods, Director

Jolnt Highway Posearin Project

FROI: : Ho Io Mifchael, Associato Dimector Joint Highway Presearch Froject मugust 9, 1961.

FII: $1-4-18$

Projoct: C-3ó-32R

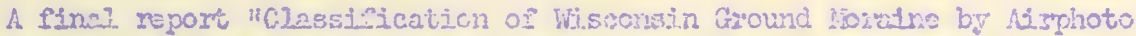
Interprotation" bJ Wesieg ?. Jouxs. Gradue.te Aseistant on our staff, is attached. The repolt was utilizec es an ISCE the si.s by Ir. Jamas. "The

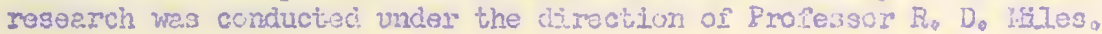

This report discusses the quemititive and qualitative differonces in the airphotc pattarns of the Farly Tazewe17, late Tazewe 11 and Casy ground morainese Fngineering propories of the various soils wero deter mined for representative samples in each of the three substages. The Cary substage is more clayey than the other tro, and the Erarly Tazewell uubstage exhibits a significant develcpraent of losss.

The afrphoto petiem elemants of topecraplyy, drainage, erosion. photo tone, vegetation, and cultuse features for cacis substage an urualit significanty cifferent such that the three substages can be distingulshed by ainghoto interpreiction.

The report is presented to the Bcard for the record.

Raspecturly suomitted.

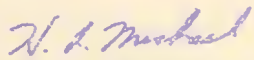

H. Is ifichrel, Associete Disector Joint Highingr Research Project

HILI8 $\mathrm{CW}$

\section{Attachment}

ccs Fo In Ashbaucher

J. I. Cooper

Wo Io Dalch

H. H. Coetz

$F$. Fo Havey
Fo So Hill工

Go A. Ieonard3

Go A. Hawbins (II, B. Scott)

Jo Fo Nolaughlin

Ro D, Miles
Ro $E_{0}$ 15177s

J. Vo Srathe

Jo so Vialing

E。 Jo Yoder 


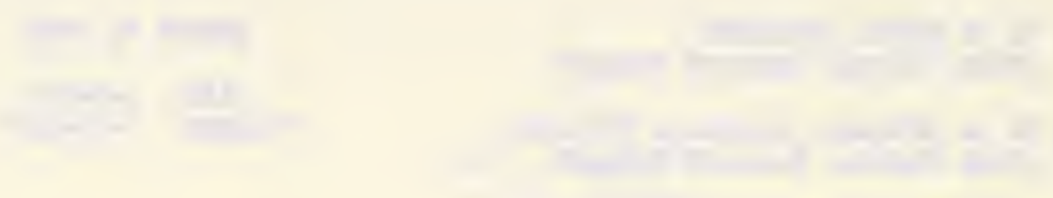


Fina? Roport

CLASSIFICATION OF WISCONSIN GROUND MORATH:

BY

ATRYHOTO DNTERPIEIATION

\section{By}

Hesloy $P$ Jare:

Graduato Assistant

Joint Hightway Pesearel Project

Fize: 1ofuris

Pioject: C-36-32R

Purclue Ualvestiony

Iafayetise Indiane

Angust 9, 9961 


\section{ACKNO'NLEDGEMENTS}

This study was sponsored by the Joint Highway Research Project at Purdue University, Professor K. B. Woods, Director. The author is grateful to this organization for providing the financial support.

The author acknowledges, with sincere appreciation the advice, oncouragement, and continued assistance given him by his major professor and advisor, R. D. Miles.

Special thanks are due to Professors H. L. Michael and K. S. Curtis for their interest and suggestions. Valuable information was also given by Professor Merle Parvis. 
TABLE OF CONTENTS

Page

LIST OF TABLES ....................... . . v

LIST OF FIGURES . . . . . . . . . . . . . . . . . . vi

ABSTRACT ........................ . vili

INTRODUCTION . . . . . . . . . . . . . . . . 1

Purpose ....................... . . . 3

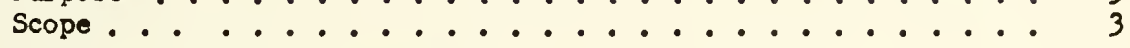

CHAPTER I. SURVEY OF LITERATURE . . . . . . . . . . . . . 4

Physiography .. . . . . . . . . . . . . . 4

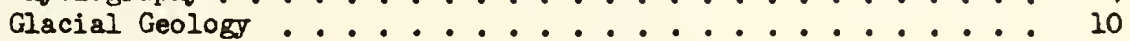

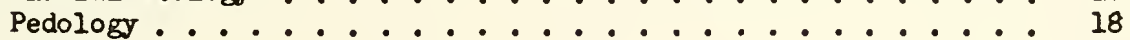

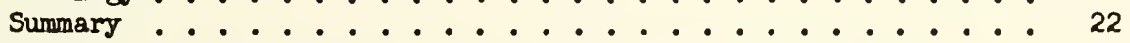

CHAPTER II. ENGINEERING PROPERTIES OF WISCONSIN SUBSTAGES . . . . 24

Procedure ...................... 24 24

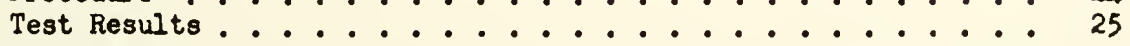

CHAPTER III. ANALYSIS AND RESULTS OF AIRPHOTO PATTERN ELERENTS

OF THE WISCONSIN SUBSTAGES . . . . . . . . . . . 34

Topography ................... 34

Regional Drainage .................. . . . . 35

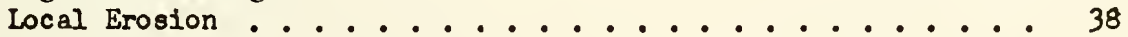

Photo Gray Tones... . . . . . . . . . . . . . 4 43

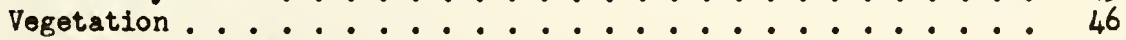

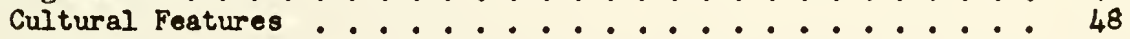

CHAPTER IV. DETAILED DESCRIPTION OF THE AIRPHOTO PATTERNS OF THE WISCONSIN SUBSTAGES ................. 51

Early Tazewell Area .................. 51

Late Tazewell Area .................. 53

Cary Area .. . . . . . . . . . . . . . . . 55

CONCLUSIONS .................... 58 
Digitized by the Internet Archive in 2011 with funding from

LYRASIS members and Sloan Foundation; Indiana Department of Transportation 


\section{TABLE OF CONTENTS (continued)}

Page

BIBLIOGRAPHY ... . . . . . . . . . . . 59

APPENDIX .......................... 63

APPENDIX B .......................... 66

APPENDIX C . . . . . . . . . . . . . . . . 73 


\section{LIST OF TABIES}

Table

1. Dates of Glacial Stages ................

2. Soil Series of the Wisconsin Drift Subsection with Percent of Area Covered by Each Series . . . . . . . . . 23

3. Results of Grain Size Analysis ............. 31

4. Results of Compaction Tests . . . . . . . . . . 32

5. Roughness Index .................. 36

6. Surmary of Drainage Densities . . . . . . . . . 39

7. Percent Man-Made Drainage ............... 40

8. Slope of Major Streams ................. 41

9. Vegetation in Percentage of Total Farm Iand ........ 47

10. Description of Farms .............. 49

C-1. Soll Sample Test Results ............... . 73 
LIST OF FIGURES

Figure

Pago

1. Physiographic Divisions of Indiana............ 5

2. Map of Indiana Showing Ridge Moralnes ........... 7

3. Indiana Bedrock Physlographic Units ... . . . . . . 9

4. Thickness of Glacial Drift............... 14

5. A Theoretical soll Profllo............... 19

6. General Agriculture Soll Regions of the Tipton Till Plain . 21

7. Engineering Classification of Solls . . . . . . . 26

8. Test Results of Early Tazewell Area Shown as Engineering Soll Profiles ................. 28

9. Test Results of Late Tazowell Area Shown as Engineering Soll Profiles ................. 29

10. Test Results of Cary Area Shown as Engineering Soil Profiles 30

11. Moisture Density Curves ..... . . . . . . . . 33

12. Topographic Map of Indiana . . . . . . . . . . . 42

13. Development of Mottled Tone in Wisconsin Ground Moraine . 45

14. Typical Early Tazewell Airphoto Patterns and Variations . . 52

15. Typical Late Tazewell Airphoto Patterns and Variations... 54

16. Typical Cary Airphoto Patterns and Variations . . . . . 56

B-1. Soll Patterns of Early Tazewell Area, Rush County . . . . 67

B-2. Soll Patterns of Early Tazewell Area, Putnam County . . . . 68

B-3. So1l Patterns of Late Tazewell Area, Tipton County . . . . 69 


\section{LIST OF FIGURES (continued)}

Figure

Page

B-4. So1l Patterns of Late Tazewell Area, Boone County . . . . 70

B-5. Soil Patterns of Cary Area, Whitley County . . . . . . . 71

B-6. Soil Patterns of Cary Area, Grant County . . . . . . . . 72 


\section{ABSTRACT}

This thesis reports the difference in airphoto patterns and engineering properties of the three substages of the Wisconsin ground moraine in Indiana. The research was part of the soil mapping program of the Joint Highway Research Project, Purdue University.

The engineering properties of the soils were determined by laboratory testing of soil samples taken in each of the three substages. The tests showed a consistent difference in the engineering properties of the parent material of the three substages.

The descriptions of the airphoto pattern elements were developed for each substage by a combined risual and stereoscopic examination of airphoto mosaics; by measurements taken on topographic maps, drainage maps, and airphoto mosaics; and by a survey of litersture. The airphotos used in this study were at a scale of $1 / 20,000$.

It is concluded that the three substages of the Wisconsin ground morainein Indiana can usually be distinguished by airphoto interpretation. 


\section{CLASSIFICATION OF WISCONSIN GROUND MORAINE}

BI

AIRPHOTO INTERPRETATION

\section{INTRODUCTION}

The cost of the rural Interstate Highway System in Indiana is estimated to be about 780 million dollars for some 786 miles of highway or about one million dollars per mile (29)*. In order to insure that the tax dollar is spent in the most efficient way, a careful study must be made of all factors affecting an engineering project.

Soil characteristics are an important factor in the location, design, and construction of a highway. Consideration of soils in the location phase allows the designer to select the most favorable conditions available. Adequate information must be available on the surface and subsurface conditions to reduce the uncertainties in the design and construction phases (8).

Soil exploration methods are classified as elther direct or indirect. The direct methods involve either penetrating, excavating, or drilling the subsurface materials (54). The indirect methods include surface and subsurface reconnaissance from geological maps, agricultural soil surveys, aerial photographs, and geophysical surveys (30). In recent years, aerial photography and the technique of airphoto interpretation has become increasingly important in engineering soil surveys.

* Numbers in parenthesis refer to Bibliography. 
Photographic interpretation may be defined as the act of examining photographic images for the purpose of identifying objects and judging their significance (5). It is the art of analyzing features on aerial photographs and by inference and logical deduction determining the characteristics of the material.

The airphoto is a record of natural and man-made features of a portion of the earth's surface. These features are a result of processes which have acted and are acting on the material to develop it into its present form. Every material has its own characteristic pattern which is composed of recognizable surface features. By interpreting data portrayed on the photograph, the general soil characteristics can be inferred. The features which the engineer uses in identifying, analyzing, and interpreting soils from the airphotos are known as the elements of the soil pattern. These elements are topography, regional drainage, ilocal erosion, photo gray tones, vegetation, and cultural features $(5,15)$. Because similar soils create similar airphoto patterns, it is usually possible to identify the soil on the basis of limited ground control and to infer important characteristics of this soil over a large region. A basic knowledge of physiography, geology, and pedology is necessary for this process.

A major soil area in Indiana is the extensive area of glacial drift. By airphoto interpretation it is possible to distinguish between and subdivide the glacial drift into the Illinoian drift and that of the Wisconsin drift. The Wisconsin drift, which covers about two-thirds of the area of the state, was formed mainly by three substages of the glacier. The limits of the substages are indicated by morainic systems. The intermorainic areas are classified predominantly as ground moraine. The three 
substages are grouped geologically into the Early Tazewell, Late Tazewell, and Cary.

\section{Purpose}

The purpose of this study was to increase the knowledge and to improve the accuracy of airphoto interpretation of soils in the Wisconsin drift areas. An attempt was made to correlate quantitatively and qualitatively the airphoto patterns with the three substages of the Wisconsin ground moraine in Indiana and to determine which soils within the three ground moraine areas have engineering propertles that might affect highway design.

\section{Scope}

As the northern part of the state is covered by outwash plains, ridge moraines, lacustrine plains, and sand dunes, the study area was limited to the ground moraines, of the Wisconsin drift which are included in an east-west strip about 70 miles wide through central Indians.

Two sample areas, each covering about one surveyed township, were selected in the ground moralnes of the three substages. Two sets of photography were used to evaluate the airphoto pattern elements within each sample area. The engineering properties of the soils were determined by investigation of existing literature and by laboratory analysis of soil samples taken in each of the six sample areas. 
CHAPTER I

SURVEY OF LITERATURE

This chapter is a summary of literature of physiography, glacial geology and pedology of the Wisconsin drift area in Indiana. A knowledge of these subjects is necessary for the engineer to understand or make use of the art of airphoto interpretation as applied to this study.

\section{Physiography.}

Indiana is located in the Interior Plains Physiographic Division (25). The area north of the Illinoian drift border is in the Central Lowland Province while the area south of this border is in the Interior Low Plateau Province as shown on figure 1.

The portion of Indiana in the Central Lowland Province is subdivided into two sections. Northern Indiana is in the Eastern Lakes and Iacustrine Plains Section while central Indiana is in the Central Till Plains Section (54). The Central Till Plains Section can be farther subdivided Into the Illinoian Drift and Wisconsin Drift Subsections as shown on figure 1. The Wisconsin Drift Subsection is sometimes referred to as the Tipton Till Plain in Indiana (27).

The Eastern Lakes and Lacustrine Plains section is characterized by lakes, lacustrine plains, outwash plains, and ridge moraines*. It contains areas of peat bogs and sand dunes. The Central Till Plains is an

* For definition of glacial land form terms, the reader is referred to Appendix A. 


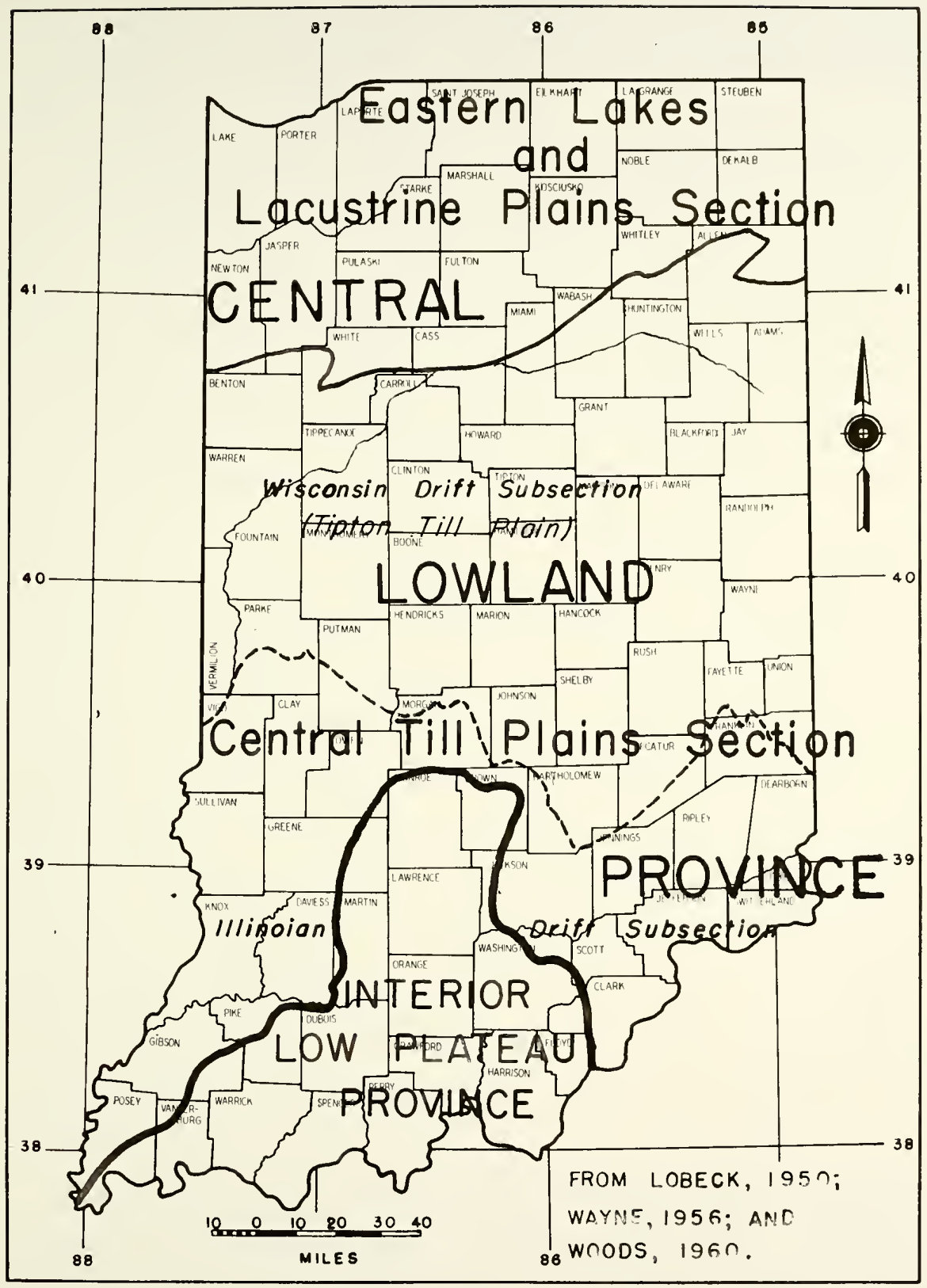

Figure 1 .

Physiographic Divisions of Indiana. 
area consisting of level or undulating deposits of drift, without lakes or appreciable stream dissection. It has only occasional breaks in topography resulting from small moraines (52).

The southern border of the Wisconsin Drift Subsection is indicated by the rather weakly developed Shelbyville moraine as shown on figure 2 (51). A large portion of the termd nal moraine is traceable only by the change in soll conditions rather than by topography (6). The weathering of the surface of the Wisconsin Drift Subsection is much less than that on the Illinoian Drift Subsection (24). The Illinoian drift exhibits a more dense development of a natural drainage system than does the W1sconsin drift.

The northern border of the Wisconsin Drift Subsection is somewhat less definite. As described by Wayne (52), the border extends almost due west from the end of the Packerton moraine into Illinois. Eastward the boundary is along the Eel River as far east as northern Allen County, where the boundary turns southeastward along Cedar Creek to the St. Joseph River in Allen County. It follows the St. Joseph Valley to the abandoned out let of Lake Maumee through the Fort Wayne Moraine as shown in figure 2. The northern boundary east of the Packerton Moraine has been modified by Wayne from that described by Malott (27). The change was made becaure of the unusual flatness of the surface between the Wabsoh and Eel Rivers which is much more characteristic of the Wisconsin Drift Subsection than the area to the north (52).

The Wisconsin Drift Subsection embraces about 4,000 square miles and is largely ground moraine containing great expanses of level land broken only by slight rises or depressions (6). It does contain several extensive morainic systems scattered throughout the area (eee figure 2). 


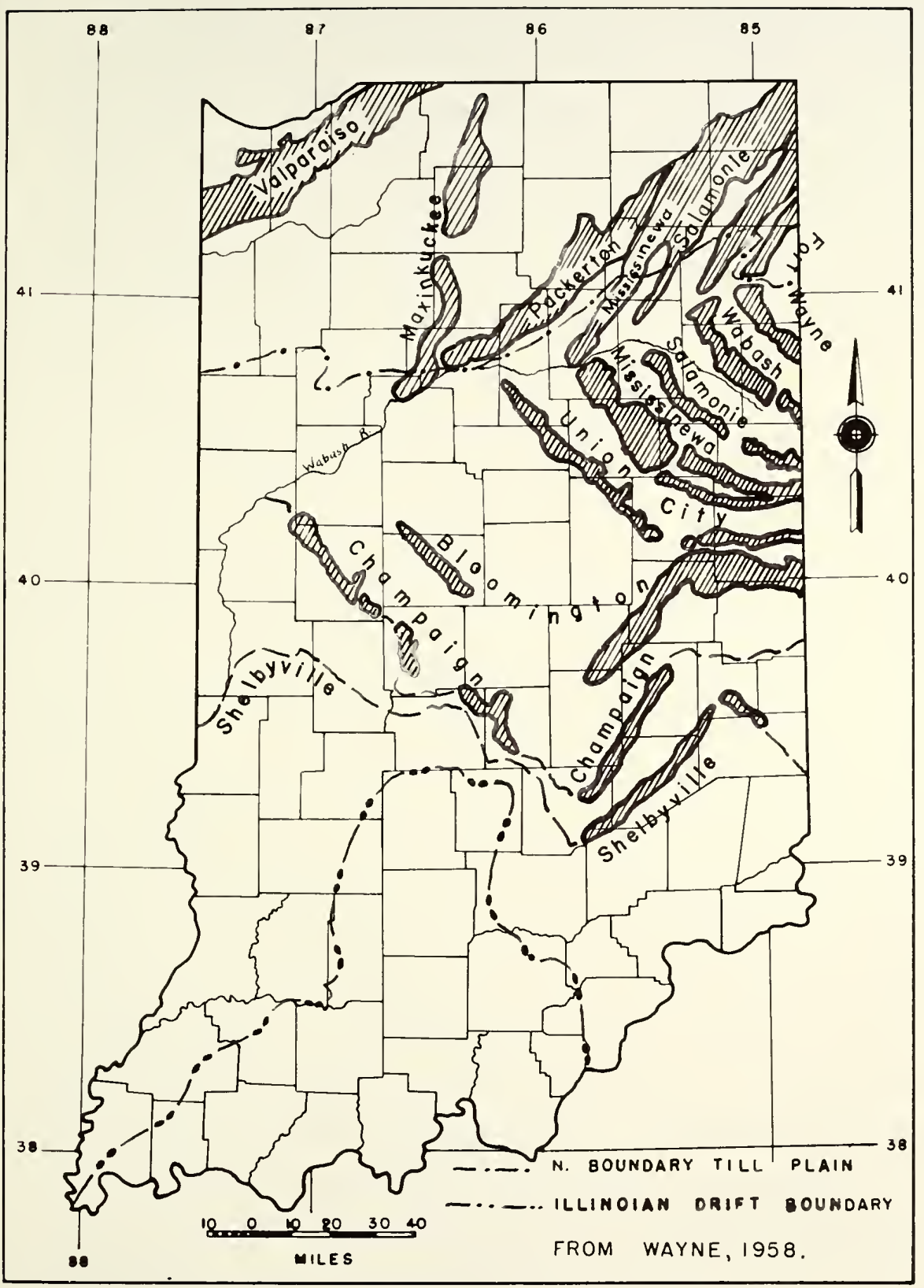

Figure 2. Map of Indiana Showing Ridge Moraines. 
Just north of the Shelbyville moraine and roughly parallel to it is the Champaign moraine. The Bloomington moraine lies north of the Champaign moraine and extends across the state in an east-west direction. Centered around glacial Lake Maumee in northeastern Indiana are a series of morainic belts. Five roughly parallel moraine are the Union City, Mississinewa, Salamonie, Wabash, and Fort Wayne moraines. As can be seen in figure 2, the Union City moraine does not extend north of the Wabash River.

The bedrock in Indiana dips gently away from the Cincinnati arch which extends from the southeastern corner of Indiana northwestward across the State (11). The rocks dip toward the Illinois coal basin (geosyncline) located near the southwest corner of Indiana, and the Michigan coal basin located in central Michigan. The dip of the rocks is the major cause of the shape of the physiographic bedrock units shown in figure 3. The older rocks are generally nearer the Cincinnati anticline (1l).

It can be seen with reference to figure $I$ and figure 3 that the main bedrock physiographic units of the Tipton Till Plain are the Bluffton Plain and the Scottsburg Lowland. Other physiographic units within the area are the Dearborn Upland, Muscatatuck Regional Slope, Norman Upland, Mitchell Plain, Crawford Upland, Sullivan Lowland, Rensselaer Plateau, and DeKalb Lowland. These physiographic features although buried by glacial drift over much of the state are the result of differential erosion on nearly flat-lying sedimentary rocks. The prevailing rock type in the lowland regions are shales while sandstone is predominant in the upland areas. In the Bluffton and Mitchell Plains, Rensselaer Plateau, and Muscatatuck Regional Slope limestone prevails. 


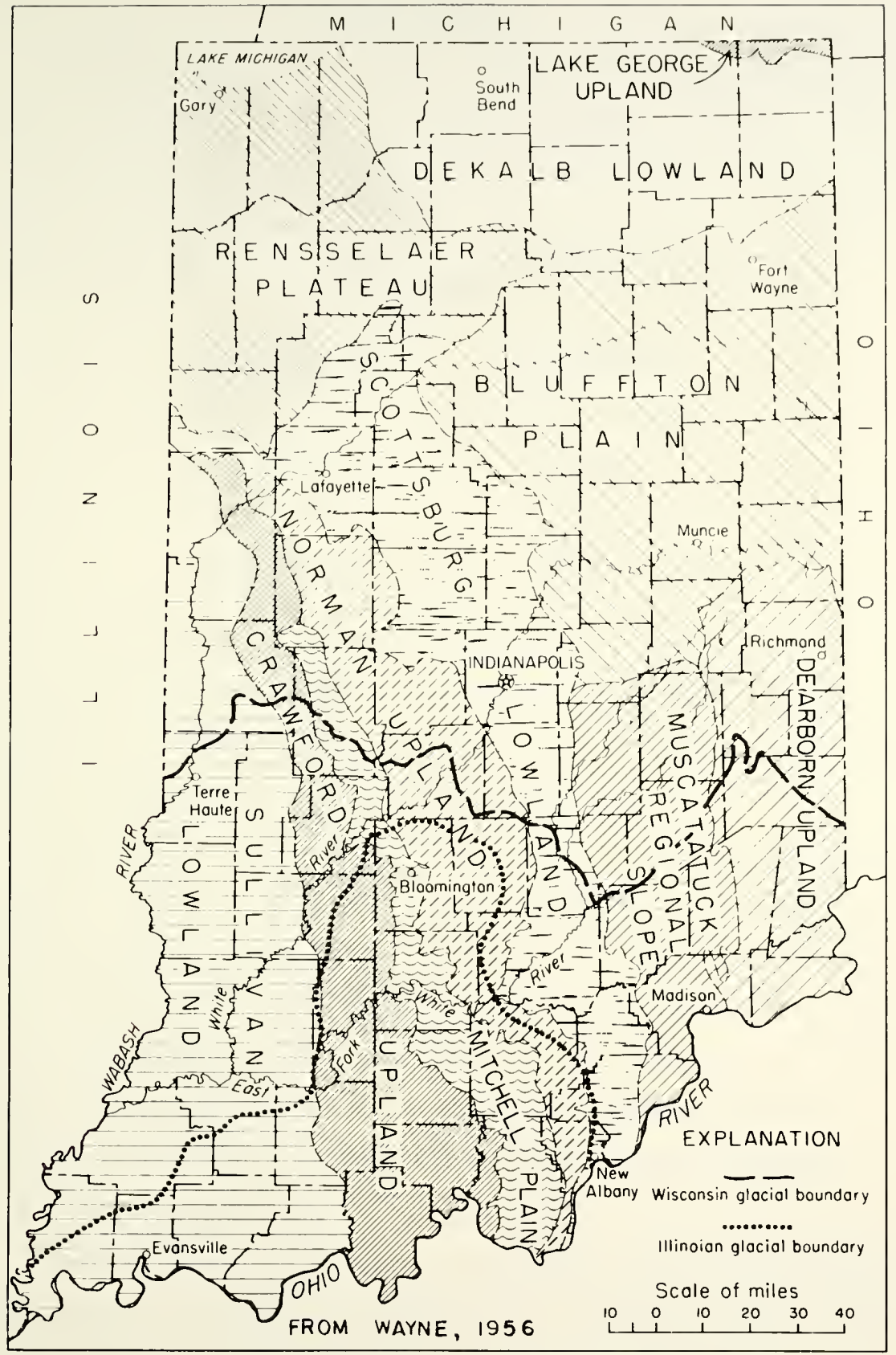

Figure 3. Indiana Bedrock Physiographic Units 


\section{Glacial Geology}

The rock surface has been buried by four distinct ice sheets advancing from the Laurentian Upland in Canada southward over the Great Lakes and into the upper Missisaippi watershed. This glaciation occurred during the Pleistocene Epoch and is called continental glaciation (31). The glacial stages are listed below with their approximate age (19):

$\begin{array}{lc}\text { Glacial Stage } & \text { Age in Years } \\ \text { Wisconsin } & 10,000-50,000 \\ \text { Illinoian } & 300,000 \\ \text { Kansan } & 700,000 \\ \text { Nebraskan } & 1,000,000\end{array}$

A glacial stage is represented by an extensive deposit of drift which is distinguished by the presence of a weathered zone at its top. The dur ation of each glacial stage is considered to have been relatively short while the interglacial stages were relatively long.

The thickness of the ice accumulations is estimated to have reached 10,000 feet (12). The thickness of the continental glacier can be estimated by performing consolidation tests on the fine-grained sediments which underlie the drift sheet deposited by a glacier. The preconsolidation pressure values can then be converted into ice thickness. This was accomplished by Harrison for an ice lobe of the Wisconsin sheet and a thickness of 2,400 feet was computed only 30 miles from the southern Wisconsin drift border (17).

It is postulated that the first ice sheet to enter the area removed the loose mantle in places and deposited it as a layer of drift. Retreat 
of the continental glacier occurred and each succeeding glacial advance picked up much of the earlier drift, reworked the material, and deposited another sheet of glacial drift. During the long periods between the advances of 1ce, weathering and erosion were going on and soils that support plant life were formed.

Glacial drift includes all deposits made by glacier ice. It includes till, stratified drift, and scattered rock fragments (38). Till has no size assortment and shows no evidence of stratification. Most of the material usually is of clay, silt, and sand size but pebbles and boulders may be present (39). Tills usually show a certain consistency in lithology which makes it possible to describe them as clayey, sandy or stoney (39). In most places the greater part of the drift is derived from nearby bedrock (39). Drift overlying shales, dolomites, and limestone is typically clayey while drift in areas of sandstone is generally sandy.

The oldest drift to be found in Indiana is from the Kansan stage. Several exposures of pre-Illinotan drift in southern Indiana have been correlated with the Kansan stage (52). The Illinois stage extended farther south than either the Kansan or the Wisconsin stages. Its southern boundary can be seen in figure 2.

The Wisconsin drift sheet is the youngest and the best preserved of the Pleistocene glacial deposits. Its history can be reconstructed more accurately than that of the older drifts. The Wisconsin drift is the only stage to show the remains of such land forms as ridge moraines, drumlins, outwash plains, kames, eskers or kettles (see Appendix A for definition of glacial terms).

Investigators at the present time generally belleve that the Wisconsin stage is composed of at least seven substages. These are: Parmdale, 
Iowan, Tazewell, Cary, Mankato, Valders, and Cochrane (19, 23).

The Wisconsin stage in Indiana consists of three recognizable areas (53). The presently accepted names are the Early Tazewell, Late Tazewell and Cary. Wayne suggests that the Early Tazewell area be correlated with the Iowan substage (53). This correlation appears reasonable to other authors but has yet to be proven (19). The name Tazewell is from Tazewell County, Illinois, and the name Cary is from a town in northeastern Illinois (23).

The Wisconsin ice sheet advanced over about two-thirds of Indiane at its greatest extent. The southern limit is marked by the Shelbyville moraine. According to Wayne the ice sheet disappeared from central Indiana then readvanced to a position a short distance north of the Shelbyville moraine (52). The limit of this advance is marked by the Champaign moraine. During the interglacial stage the ground moraine between the Shelbyville and Champaign moraines was covered with a thin layer of loess from 18 to 40 inches thick $(16,40,53)$. This area is called the Early Tazewell area.

After forming the Champaign moraine the ice sheet formed the Bloomington morainic system. This moraine apparently does not mark any great soil discontinuity. When the ice sheet had retreated to the vicinity of the present southern end of the Parkerton moraine, shown in figure 3, the ice sheet separated into the Michigan, Saginaw, and Erie lobes (27). The ice continued to retreat until the Erie lobe had completely disappeared from Indiana. This caused the formation of a lake near the present lacustrine deposits of glacial Lake Maumee east of the Fort Wayne moraine (52). The ice sheet then advanced, the Erie lobe moved over the clayey 
lacustrine deposits to form the present Cary substage. This caused the till of the Cary substage in northeast Indiana to be more clayey than the remainder of the Wisconsin Drift subsection (53).

The outer boundary of the Cary area has not been definitely established. Leighton says the Union City moraine is the outer boundary (22), while Wayne states that the Mississinewa moraine marks the farthest readvance of the Erie lobe (53). In this study the Union City moraine is used as the boundary as it marks a pedological soil discontinuity, discussed subsequently.

The Late Tazewell area is bounded on the south by the Champaign moraine and on the north by the north boundary of the Wisconsin Drift Subsection and the Union City moraine. The boundaries of the Wisconsin substages can be seen in figure 2.

The thickness of glacial drift is determined largely by the relief of the underlying bedrock. Figure 4 shows the depth of drift north of the Shelbyville moraine (52). It can be seen that the thickness of drift in the Early Tazewell area is generally less than 50 feet while in the Late Tazewell and Cary areas it is usually greater than 50 feet. Glacial substages may be distinguished by numerous methods. Four basic methode are: topographic evidence, weathering or depth of leaching, radioactive dating, and interglacial deposits.

Substages of the Wisconsin can to some degree be distinguished on the basis of the freshness of the glacial topography. Drainage Iines are more extensive on the Tazewell than on the Cary substage which has numerous closed basins (39). Ruhe states that in Iowa the Tazewell drift surface is well drained, whereas the Cary surface is undrained (35). 


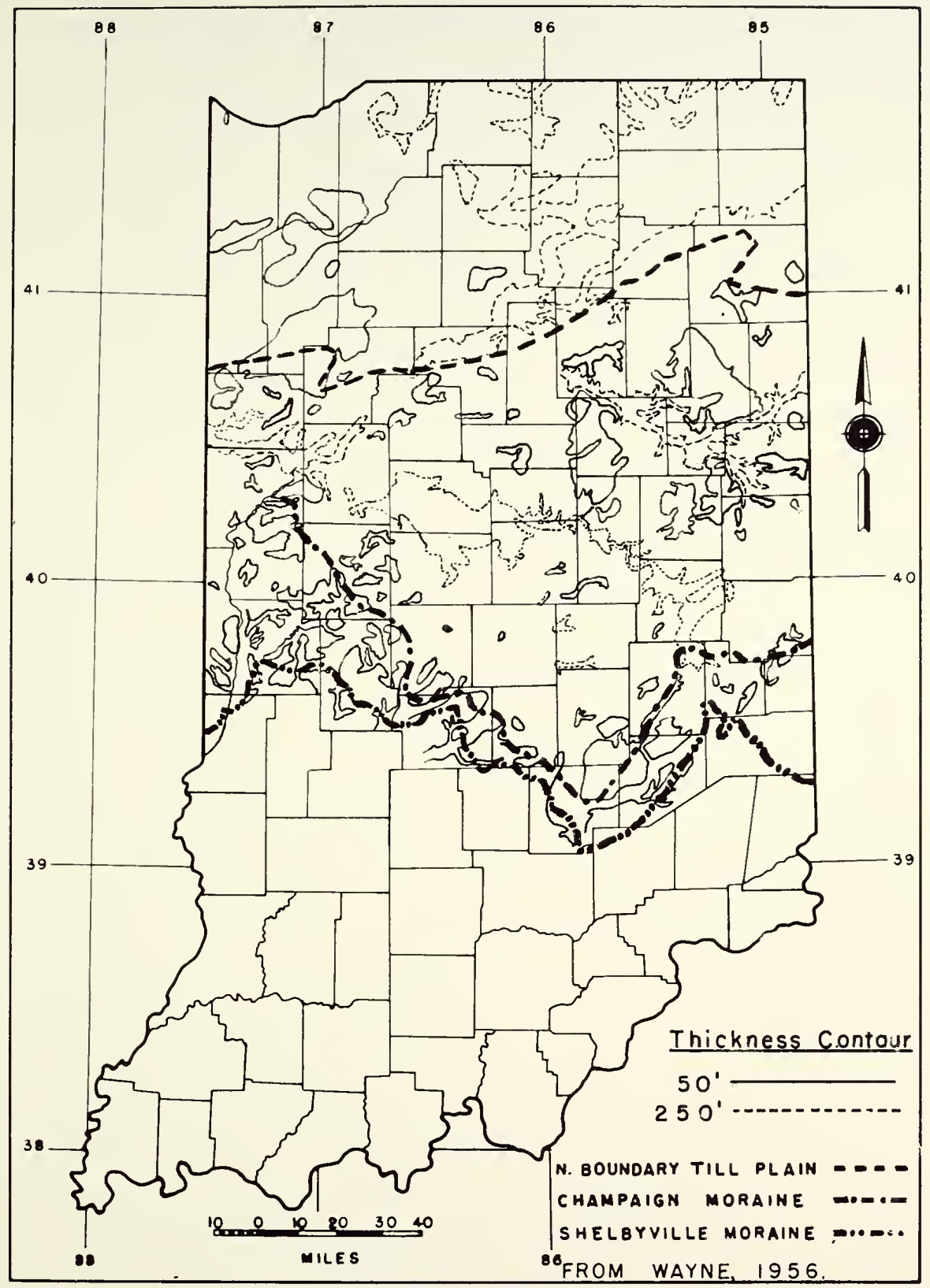

Figure 4 .

Thickness of Glacial Drift. 
The topography of a ground moraine reflects the material composing the drift. Thornbury states that clayey ground moraines give rise to flat or gently undulating surfaces while a granular ground moraines give rise to a knob and baein type topography (39). This is because the angle of repose for granular drift is greater than for clayey drift (39).

The depth of leaching is an important method of distinguishing glacial materials when the till is calcareous. Till under similar conditions of parent material, climate, vegetation and topography, will have different depths of leaching depending on their age. Typical depths of leaching for some of the Wisconsin substages in midwestern states are: Iowan, 5 to 6 feet; Tazewell, 4 to 5 feet; Cary, 3 to 4 feet (39).

Flint found in Indiana that the average depth of leaching behind the Shelbyville moraine was 51 inches, behind the Champaign moraine it was 42 inches, and behind the Bloomington moraine it was 38 inches (13). Good1ng, Thorp, and Gamble believe that the soil discontinuity between the Shelbyville and Champaign tills does not indicate a significant time interval between the two tills. The greater depth of leaching of the Shelbyville till is due to the greater thickness of fast-leaching loess on that till (16). Also, Flint reports a depth of leaching for the Tazewell substage in IIIinois of 48 inches and a depth of leaching of 62 inches for the Iowan substage in Iowa (13). It can be seen that the depth of leaching in the Early Tazewell area in Indiana is more comparable to the Tazewell substage in Illinois than the Iowan substage in Iowa. This correlation may, however, be due to climate and not age.

Radiocarbon dating is probably the most accurate method of dating glacial deposits although any single radiocarbon age determination may 
be erroneous because of contamination of the sample by either older or younger materials (19). The rather short half life of $c^{14}$ limits its use for dating to a maximum of 45,000 years (12).

Another method of dating glacial stages is by ocean core samples. Hough in 1947 collected core samples of the sea-bottom in the Pacific Ocean (20). These samples contained several layers of red clay and globigerina ooze. The clay which was low in carbonate was correlated with cold-water conditions while the ooze which was high in carbonate was correlated with warm-water conditions. This is because carbonates are more soluble in cold water than in warm water. The age of the various layers were determined by the percent of equilibrium between uranium, Ionfum, and radium. These layers were then correlated with the glacial stages. This method is valid to an age of about 300,000 years, but percentage of error is not known (19). Dates determined by this method are somewhat older than those determined by the radiocarbon method. Dates of the glacial stages by leaching, radiocarbon dating, and by sea-bottom core sample are shown in table 1.

Interglacial deposits and buried soil horlzons is an effective method of differentiating two substages. In Putnam County, $1-1 / 2$ miles southwest of Greencastle, the Early Tazewell drift is separated from the IIlinolan drift by a layer of loess several feet thick (6). Radiocarbon dating of wood found in this loess established an age of 19,500 years. This would indicate that the Farly Tazewell drift is of a younger age than the underlying loess or about 4,000 years younger than the Iowan substage. 
TABLE 1

DATES OF GLACIAL STAGES

AGE IN MBARS

\begin{tabular}{lccr}
\hline Glacial Stage & $\begin{array}{c}\text { Depth of } \\
\text { Loaching (9) }\end{array}$ & $\begin{array}{c}\text { Pacific Ocean } \\
\text { Core Sample (20) }\end{array}$ & Radiocarbon \\
\hline $\begin{array}{l}\text { Wisconsin } \\
\text { Cochrane }\end{array}$ & & None & $7,500(10)$ \\
Valders & & 11,000 & $11,000(14)$ \\
Mankato & 20,000 & 15,000 & $12,000(14)$ \\
Cary & $50-180,000$ & 26,000 & $13,000(37)$ \\
Tazewell & & 37,000 & $17,000(36)$ \\
Iowan & & 51,000 & $24,000(22)$ \\
Farmdale & & 64,000 & $29,000(22)$ \\
& & &
\end{tabular}




\section{Pedolog:}

Pedology is the science of soil morphology and soil genesis (54). It is a study of soil in its natural stats (6). The pedologist considers 8011 to be that portion of the earth's surface which supports plant life. For the engineer, an understanding of pedology provides an additional method for determining subsurface soil conditions. This is especially true for airphoto interpretation studies.

The pedological concept is based on the premise that like soil-forming materials, if subjected to identical environmental conditions of climate, topography, and time, will develop identical soil profiles (54). The parent material and topography can be determined from the aerial photograph while the climate and relative age can be determined from existing literature. The pedological soll can then be identified with limited ground control. If the soll profile has previously been correlated with engineering characteristics, the engineering properties of the soil under photo analysis can be inferred (6).

The soil profile is a vertical section of the soil extending into the unaltered parent material. Pedologists separate the profile into a number of layers, called horizons, and each has its own characteristics. Figure 5 shows a theoretical soil profile. The surface layer or A horizon, is the zone of minimum clay content; the next layer is the B horizon, or zone of accumulation of clay; below the $\mathrm{B}$ is the $\mathrm{C}$ horizon, or unaltered parent material. The A and B horizons together constitute the solum or true soil (43).

Simple units of pedological classification of soils are catena, series, and type. A catena is a group of soil series developed from similar parent material under the same vegetative cover but differing in characteristic 


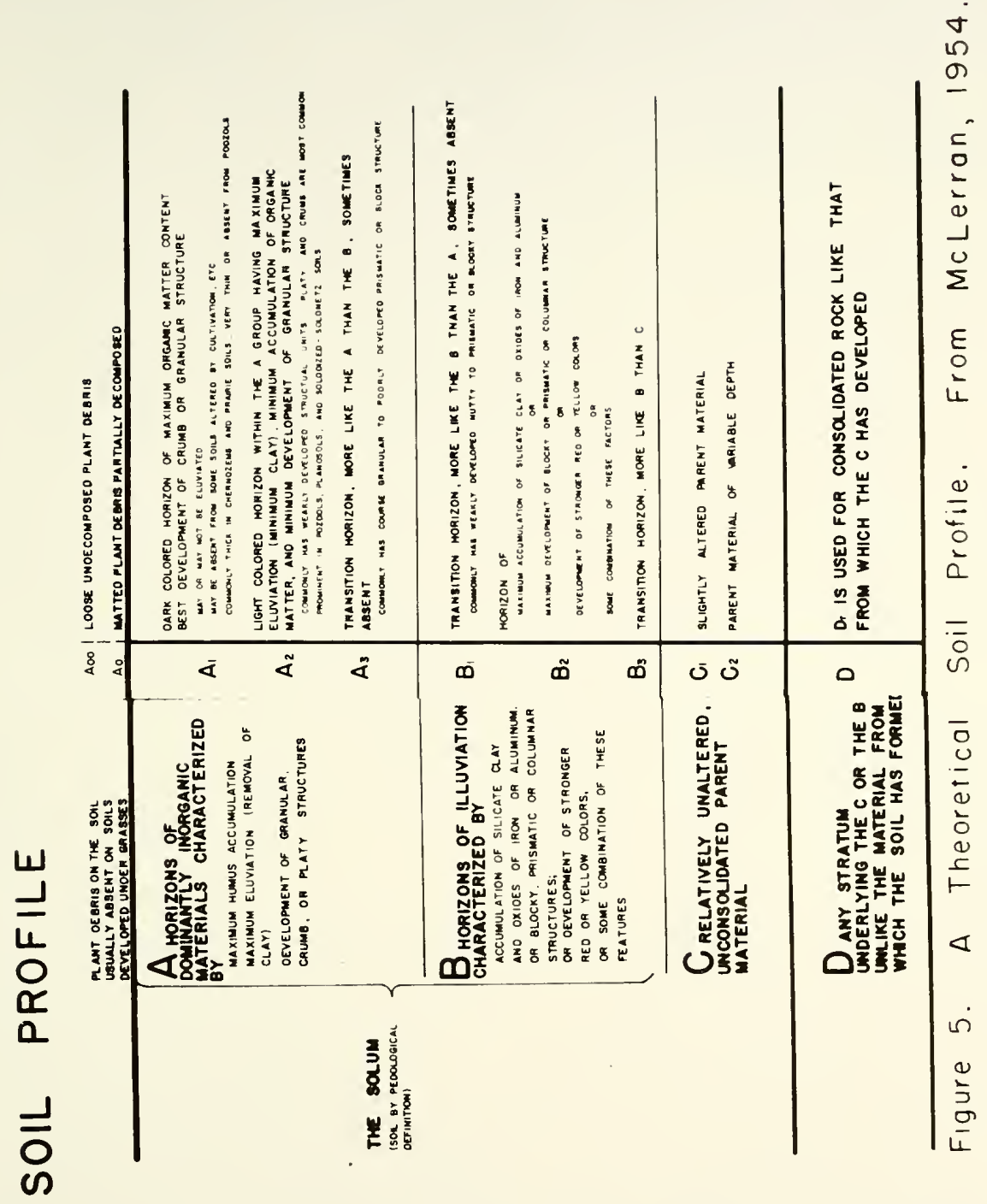

岌 
of the solum owing to differences in relief or drainage (41). Ideally, the soils comprising a catena occur as consecutive bands around a basin or a hill (42). Catena members are called series. Thus, if the soil catena is known for an area, the soil series can be determined by measuring or estimating the slope or drainage condition.

The soil series is defined as a group of soils having similar soil profiles except for the texture of the A horizon. All the soils within a series must be developed from similar parent material under similar environmental conditions (age, climate, vegetation, and relief) (43). The soil series are given names taken from place names near the spot where the soil was first defined, such as Hagerstown, Mohave, Houston, and Fargo (43).

The definition of a soil type is identical with that of soil series, except the texture of the $\mathrm{A}$ horizon does not vary significantly. The texture of the A horizon, such as sand, sandy loam, loam, silt loam, clay loam, or clay, is added to the series name to give the complete name of the soil type (43).

Agriculture soil surveys portray essentially four general soil regions in the Wisconsin Drift Subsection (9). These are shown in figure 6. The soils of the till plain northwest of the Wabash River (region 4) differ from the remainder of the till plain because they were developed in a prairie region. The soils (region 1, 2, and 3) southeast of the Wabash River are forest soils. The prairie soil region was not included in this study.

The Shelbyville, Champaign, and Union City moraines are also shown in figure 6. It can be seen that the borders of the soil regions are 


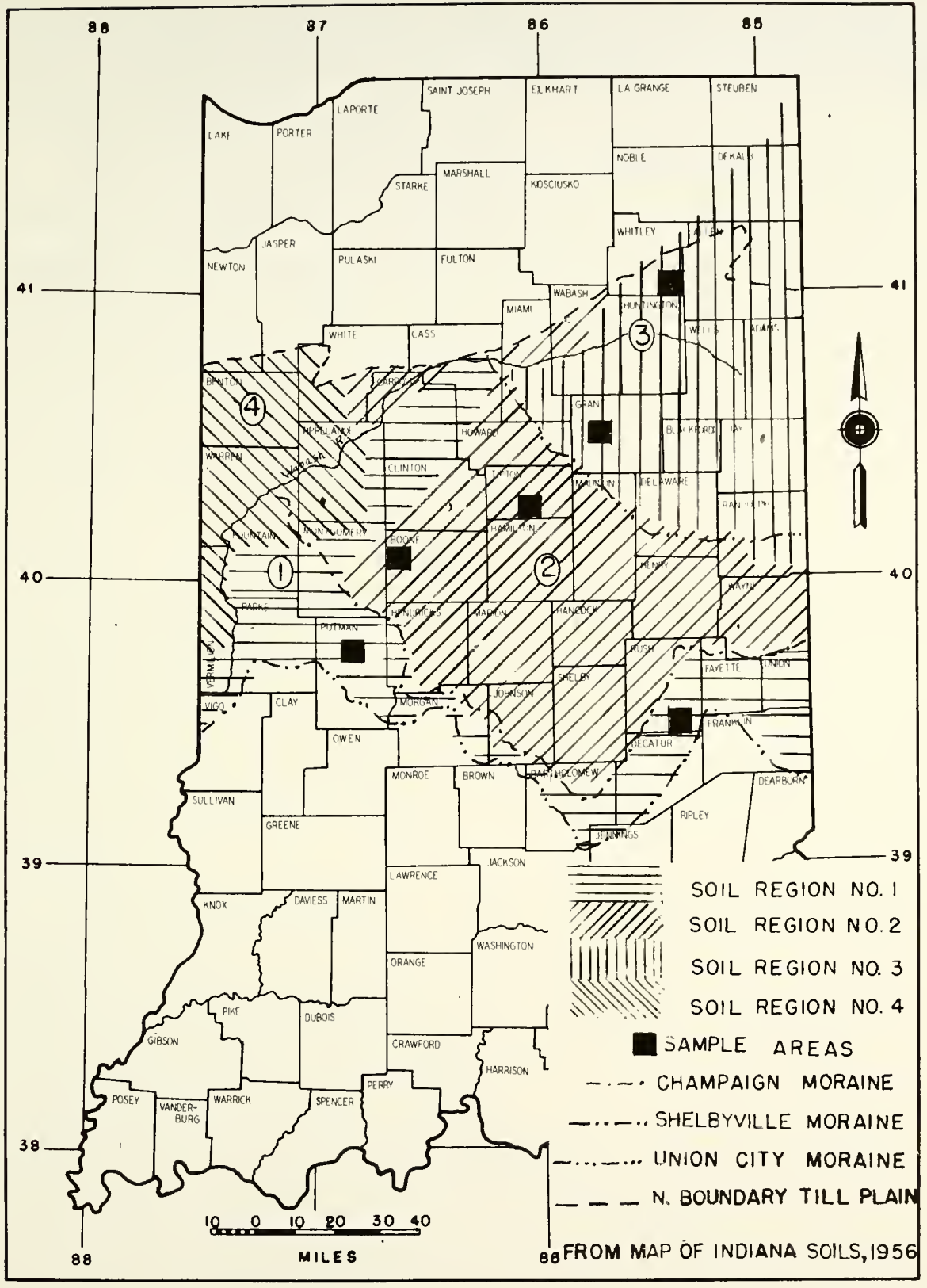

Figure 6. General Agriculture Soil Regions of the Tipton Till Plain. 
almost identical to the moraines, except just east of the Wabash River. This discrepancy is due to the westerly wind blowing loess from the Wabash floodplain onto the Late Tazewell area.

Table 2 shows the major pedological soil series mapped in the soil regions of the Wisconsin Drift Subsection (21). The table also shows percentage of area covered by each soil series (9). It can be seen that the percent of area with soils in the $4-15$ percent slope class decreases from the Early Tazewell, to the Late Tazewell, to the Cary region, while the percent of area with depression soils increases. This is due to the better development of natural drainage in the Early Tazewell area (9).

\section{Summary}

The Wisconsin Drift Subsection in Indiana is composed of three substages of the Wisconsin glacial stage. The presently accepted names of these areas are the Early Tazewell, Late Tazewell, and Cary. The Early Tazewell and Late Tazewell areas are separated by the Champalgn moraine while the Late Tazewell and Cary areas are separated by the Union City moraine.

Although glacial drift is not uniform over an area and its composition is dependent to some degree on the underlying bedrock, it can be expected that the parent material in the Cary area is more clayey than in the remainder of the Wisconsin Drift Subsection. Also, the soils in the Farly Tazewell area can be expected to have a more silty $B$ horizon than the soils in either the Late Tazewell area or in the Cary area. 


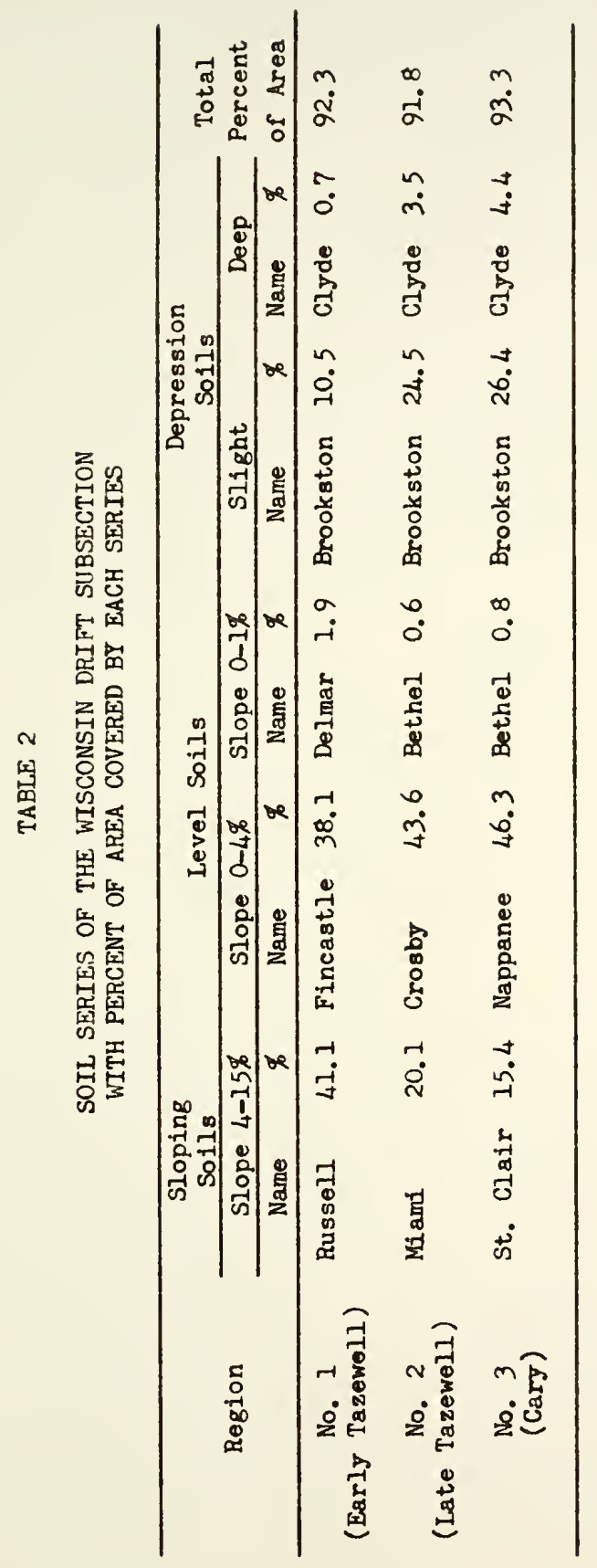


CHAPTER II

ENGINEERING PROPERTIES OF VISCONSIN SUBSTAGES

The classification of the Wisconsin ground moraine required the correlation of airphoto patterns with the engineering characteristics of the soil. As existing soil data were not sufficient, a number of soil samples were collected and tested.

\section{Procedure}

Six sample areas each covering about one township were selected in the ground moraines of the Wisconsin Drift Subsection as shown in figure 6. Two sample areas were selected in each of the three substages in an attempt to represent average conditions throughout the entire area of the ground moraine.

In each of the six sample areas, a smaller area covering about one square mile was mapped showing the major pedological soil series. As it is very difficult to determine all the slope classes on airphotos at a scale of $1 / 20,000$ (30), only the main sloping, level and depression soil series were mapped in each area. These correspond to the Russell, Fincastle, and Brookston soils in the Early Tazewell area; the Miami, Crosby, and Brookston soils in the Late Tazewell area; and the St. Clair, Nappanee, and Brookston soils in the Cary area. It should be noted that while the Brookston series has been mapped as the depression soil in each area, they 
do not necessarily have the same engineering properties as they have been developed from different parent material. Airphoto stereo coverape of these areas can be seen in Appendix B. An acetate overlay is also shown with the pedological soil boundaries. The boundaries were drawn by estimating the slope class from stereoscopic viewing.

Eighteen test sites were then selected, one in each of the three pedological soil series mapped in each of the six test areas. The location of the test sites is shown in Appendix B. At each test site, soil samples were taken from at least the $B$ and $C$ horizon. In order to sample the loess cover, three samples were taken at most sites in the Farly Tazewell area, two in the $\mathrm{B}$ horizon and one in the $\mathrm{C}$ horizon. A total of 44 samples were collected.

Atterberg limits, grain size, and compaction tests were conducted on the samples by the Joint Highway Research Project Soils Laboratory. The tests were conducted according to the American Association of State Highway Officials (AASHO) specifications. The soil samples were classified according to the AASHO Soil Classification System, the Unified Soil Classification System (USCS), and the classification system shown in figure 7 .

\section{Test Results}

The results of the soil tests are summarized in Appendix C. It can be seen that the Unified Soil Classification System shows little difference between the samples as all but six of the 44 samples tested were classified as CL. These six samples were in the Late Tazewell area.

The AASHO Classification System which is based on field performance of highways (33) does indicate a difference as the classification of the 


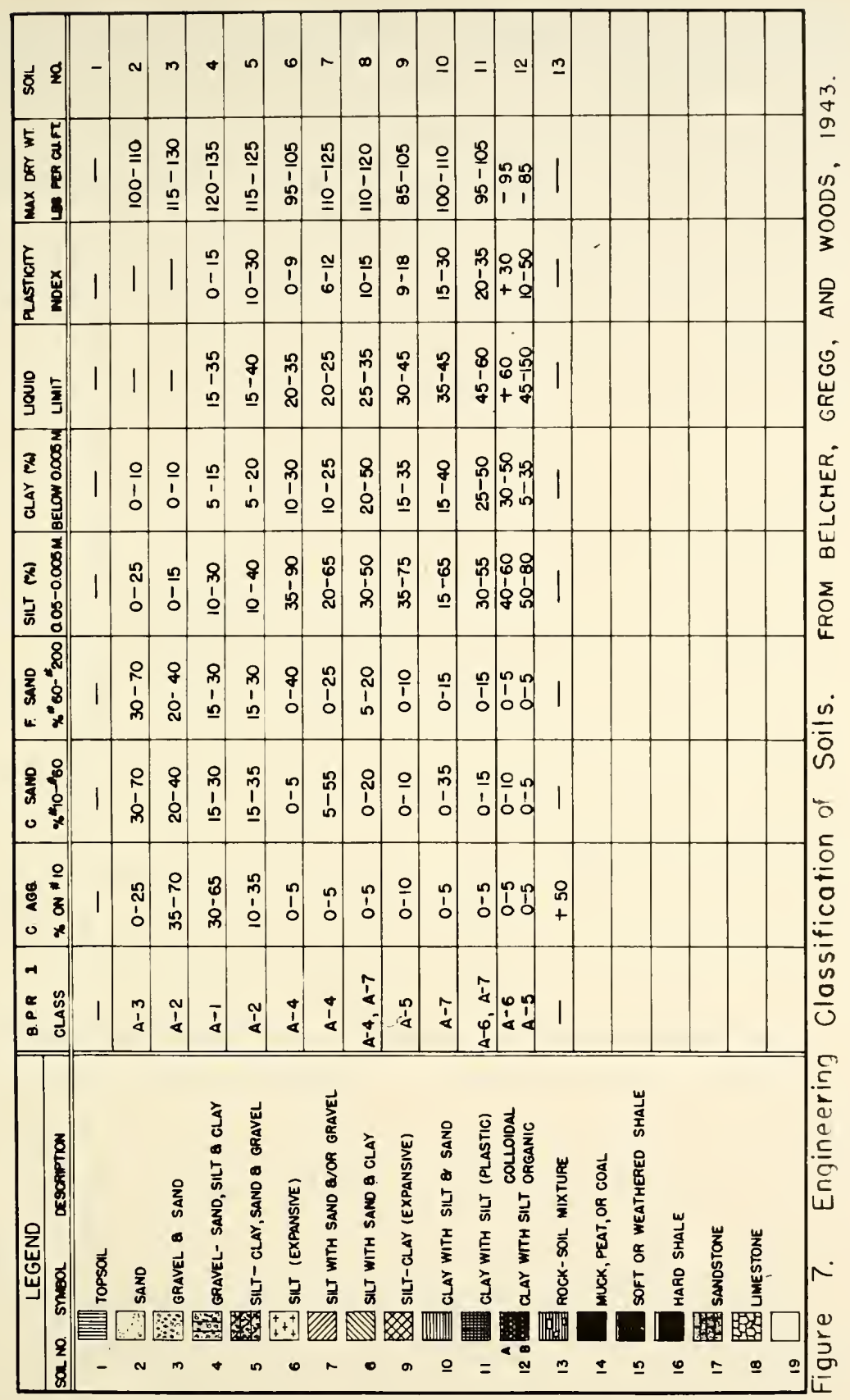


samples ranges from $\mathrm{A}-4(1)$ to $\mathrm{A}-7-6(16)$. A sumary of the classification by the AASHO system is shown in figures 8, 9, and 10 as engineering soil profiles for the Early Tazewell, Late Tazewell and Cary areas respectively. The cross-hatched symbols refer to the classification system in figure 7. According to figure 7, the parent material is predominantly silt with clay and sand in the Early Tazewell area, silt with sand in the Late Tazewell area, and clay with silt and sand in the Cary area. The B horizon is almost uniformly classified as clay with silt and sand except in the Cary area which is classified as clay with silt.

Results of grain size analysis is shown in table 3. The average silt content in the top of the B horizon is the greatest in the Early Tazewell area, but is insufficient to affect the soil classification. The average percent of clay in the parent material is 33, 28, and 49 for 'the Early Tazewell area, Late Tazewell area, and Cary area respectively. The average maximum density and optimum moisture content for each area are shown in table 4. It can be seen that there is little difference between samples taken in the $B$ horizon. Compaction tests on samples taken in the parent material does indicate a difference. The maximum densities for parent material samples in the Early Tazewell, Late Tazewell, and Cary areas were 119, 123, and 110 pounds per cubic foot respectively. Moisture density curves are shown in rigure 11 for the parent material samples taken in the level and depression soils in each area. The samples taken in the sloping soils were omitted from the graph in order to avoid conjestion. This does not affect the result as the compaction tests on samples taken in the level and sloping soils were similar. It can be seen in figure 11 that the curves show consistently lower maximum densities and higher optimum moisture contents for the Cary samples than for the Tazewell samples. 

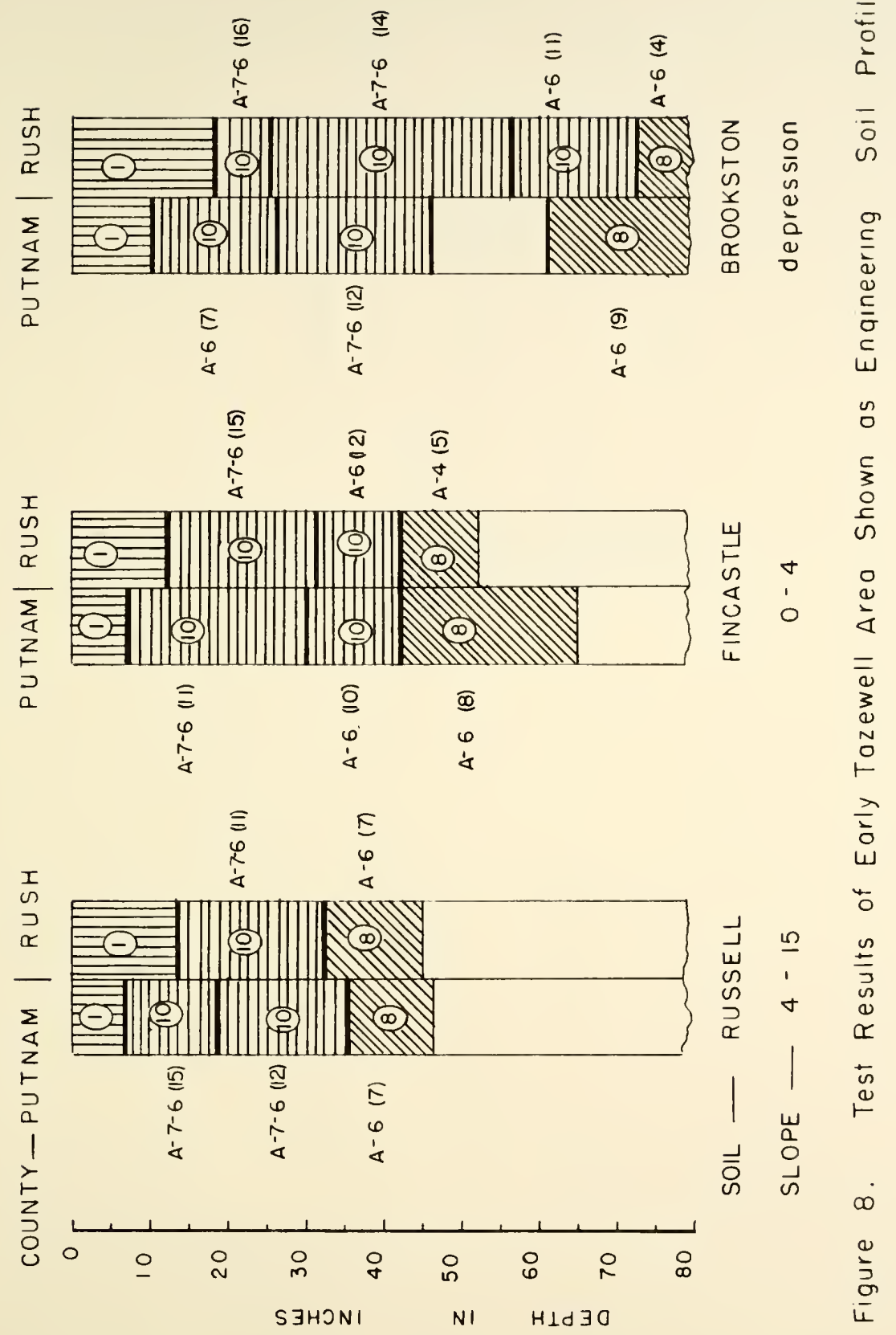

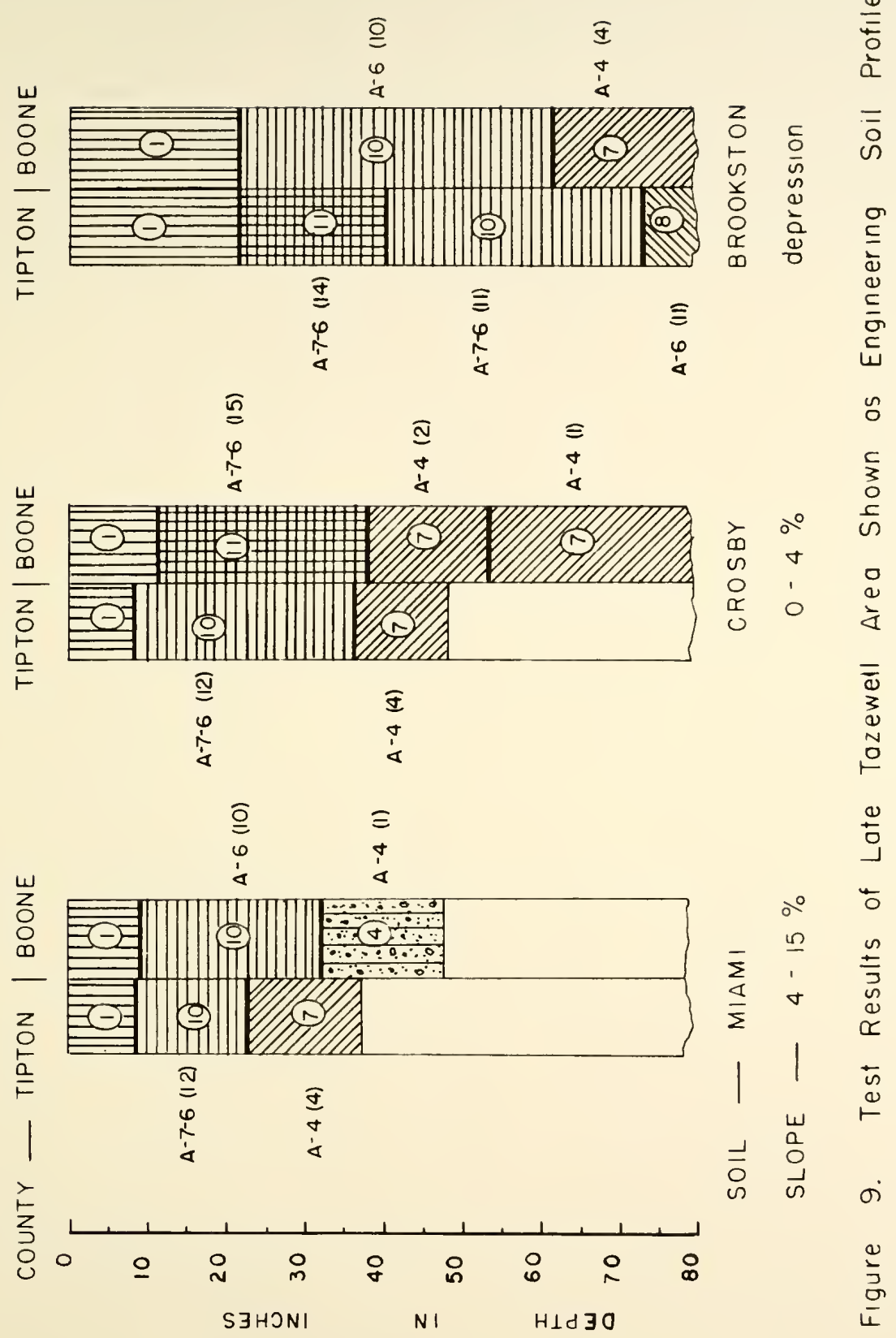

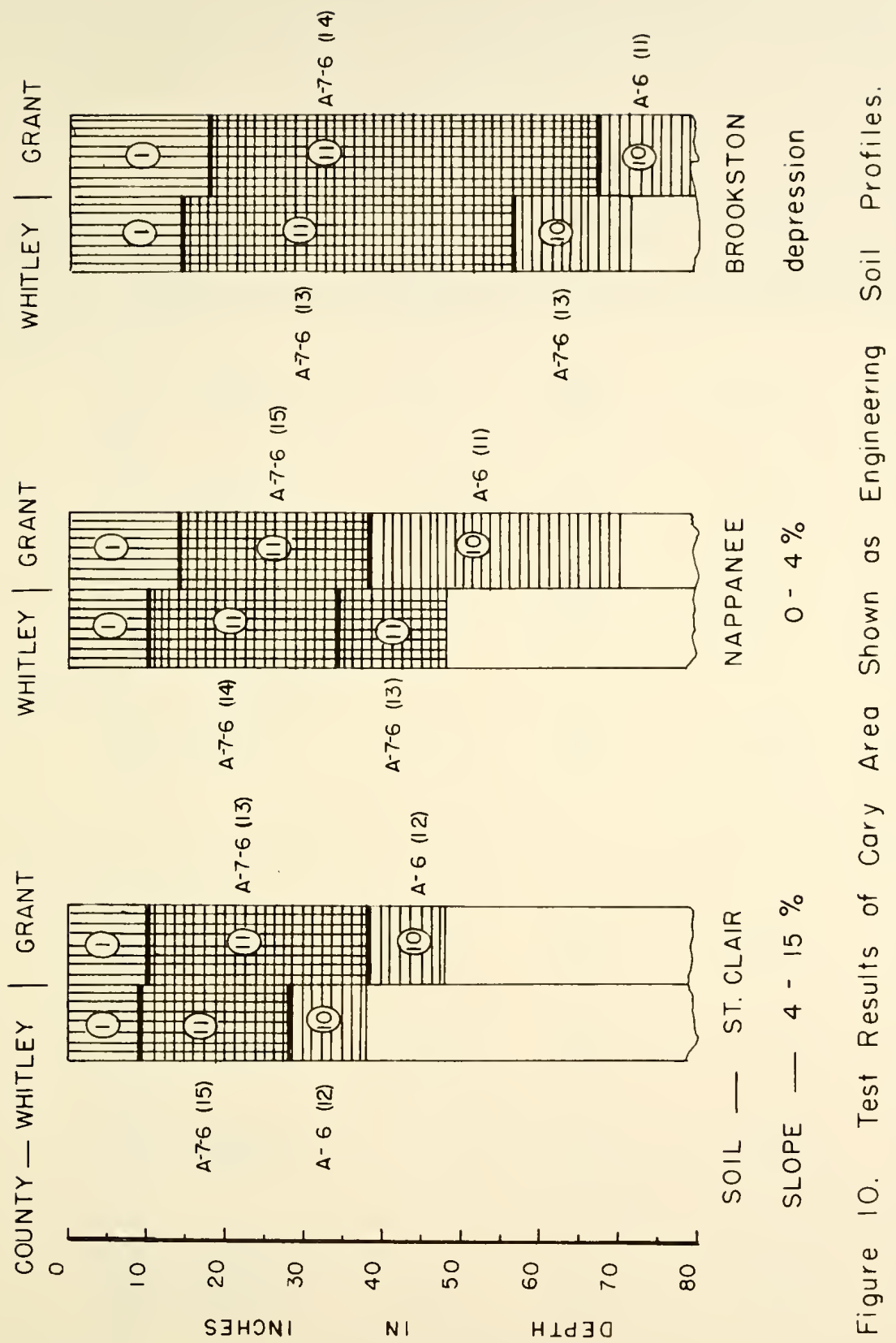
TABLE 3

RESULTS OF GRAIN SIZE ANALYSIS

\begin{tabular}{|c|c|c|c|c|}
\hline $\begin{array}{c}\text { SAMPLE LOCATION IN PROFILE } \\
\text { Soil Slope Class } \\
\text { Location }\end{array}$ & $\begin{aligned} \% \\
>2.0 \mathrm{~mm} \\
\text { Gravel } \\
\end{aligned}$ & $\begin{array}{c}. \% \\
2.0-.074 \mathrm{~mm} \\
\text { Sand }\end{array}$ & $\begin{array}{c}\% \\
.074-.005 \mathrm{~mm} \\
\text { silt } \\
\end{array}$ & $\begin{array}{c}\phi \\
<.005 \operatorname{mm} \\
\text { Clay } \\
\end{array}$ \\
\hline \multicolumn{5}{|l|}{$\begin{array}{l}\text { TOP OF B HORIZON } \\
4-15 \%\end{array}$} \\
\hline Early Tazewell & 0 & 16 & 44 & 40 \\
\hline Late Tazewell & 3 & 28 & 34 & 35 \\
\hline $\begin{aligned} \text { Cary } \\
0-4 \%\end{aligned}$ & 2 & 22 & 27 & 49 \\
\hline Early Tazewell & 0 & 6 & 55 & 39 \\
\hline Late Tazewell & 1 & 12 & 48 & 39 \\
\hline Cary & 0 & 12 & 38 & 50 \\
\hline Depression & & & & \\
\hline Early Tazewell & 1 & 20 & 44 & 35 \\
\hline Late Tazewell & 2 & 20 & 37 & 41 \\
\hline Cary & 2 & 19 & 32 & 47 \\
\hline Average for all soils & & & & \\
\hline Early Tazewell & 0 & 14 & 48 & 38 \\
\hline Late Tazewell & 2 & 20 & 40 & 38 \\
\hline Cary & 1 & 18 & 32 & 49 \\
\hline
\end{tabular}

PARENT MATERIAL

$\begin{array}{lrlll}\text { 4 - 15\% } & & & & \\ \text { Early Tazewell } & 9 & 29 & 30 & 32 \\ \text { Late Tazewell } & 10 & 40 & 28 & 22 \\ \text { Cary } & 4 & 21 & 32 & 43 \\ \text { - } 4 \% & 10 & 28 & 26 & 36 \\ \text { Early Tazewell } & 18 & 33 & 24 & 25 \\ \text { Late Tazewell } & 3 & 12 & 31 & 54 \\ \quad \text { Cary } & 9 & 31 & 30 & 30 \\ \text { Depression } & 4 & 22 & 36 & 38 \\ \text { Early Tazewell } & 3 & 18 & 28 & 51 \\ \text { Late Tazewell } & & & & \\ \text { Cary } & 9 & 29 & 29 & 33 \\ \text { Average for all soils } & 11 & 32 & 29 & 28 \\ \text { Early Tazewell } & 3 & 17 & 31 & 49 \\ \text { Late Tazewell } & & & & \end{array}$


TABLE 4

RESULTS OF COMPACTION TESTS

\begin{tabular}{|c|c|c|c|c|c|c|}
\hline \multirow{2}{*}{$\begin{array}{l}\text { Samplo Profile Position } \\
\text { Soll Slope Class }\end{array}$} & \multicolumn{2}{|c|}{ Early Tazewell } & \multicolumn{2}{|c|}{ Late Tazewell } & \multicolumn{2}{|c|}{ Carr } \\
\hline & $\begin{array}{l}\text { Density } \\
1 \mathrm{~b} / \mathrm{ft}^{3}\end{array}$ & $\begin{array}{l}\text { Optimum } \\
\text { Water } \%\end{array}$ & $\begin{array}{l}\text { Density } \\
1 \mathrm{~b} / \mathrm{ft}^{3}\end{array}$ & $\begin{array}{l}\text { Optimum } \\
\text { Water } \%\end{array}$ & $\begin{array}{l}\text { Density } \\
1 \mathrm{~b} / \mathrm{ft}^{3}\end{array}$ & $\begin{array}{l}\text { Optimum } \\
\text { Water } \varnothing\end{array}$ \\
\hline \multicolumn{7}{|l|}{ B Horizon } \\
\hline $\begin{array}{l}4-15 \% \\
0-4 \% \\
\text { Depression }\end{array}$ & $\begin{array}{l}105 \\
107 \\
107\end{array}$ & $\begin{array}{l}18 \\
19 \\
19\end{array}$ & $\begin{array}{l}107 \\
107 \\
108\end{array}$ & $\begin{array}{l}18 \\
20 \\
18\end{array}$ & $\begin{array}{l}104 \\
105 \\
106\end{array}$ & $\begin{array}{l}20 \\
20 \\
19\end{array}$ \\
\hline AVERAGE & 106 & 19 & 107 & 19 & 105 & 20 \\
\hline \multicolumn{7}{|l|}{ Parent Material } \\
\hline $\begin{array}{l}4-15 \% \\
0-4 \% \\
\text { Depression }\end{array}$ & $\begin{array}{l}118 \\
218 \\
120\end{array}$ & $\begin{array}{l}14 \\
14 \\
14\end{array}$ & $\begin{array}{l}124 \\
126 \\
120\end{array}$ & $\begin{array}{l}11 \\
11 \\
14\end{array}$ & $\begin{array}{l}113 \\
110 \\
108\end{array}$ & $\begin{array}{l}16 \\
18 \\
19\end{array}$ \\
\hline AVEPAGE & 119 & 14 & 123 & 12 & 110 & 18 \\
\hline
\end{tabular}




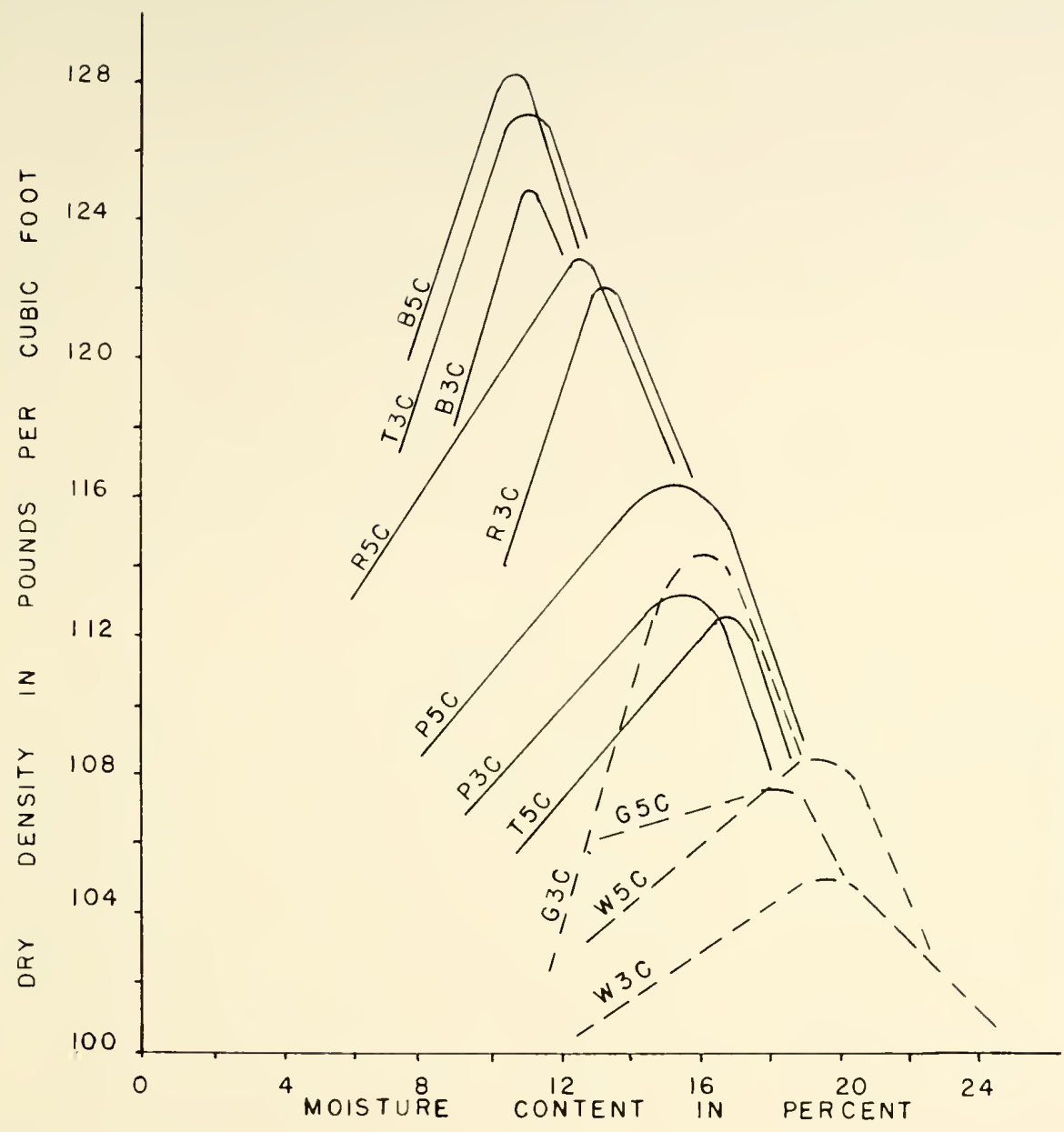

LEGEND

- - CARY SAMPLES

TAZEWELL SAMPLES

SAMPLE . NUMBER

FIRST LETTER IS COUNTY: P-PUTNAM, R-RUSH, T-TIPTON, B-BOONE, W-WHITLEY, G-GRANT.

NUMBER IS SOIL SLOPE, 3-LEVEL, 5-DEPRESSION,

LAST LETTER IS PROFILE HORIZON.

Figure 11. Moisture Density Curves. 
CHAPTER III

\section{ANALYSIS AND RESULTS OF AIRPHOTO PATTERN ELENENTS \\ OF THE WISCONSIN SUBSTAGES}

The airphoto pattern of soil is composed of six elements. These are topography, regional drainage, local erosion, photo gray tone, vegetation, and cultural features.

\section{Topography}

The topography resulting from materials of deposition often has characteristics which identify the mode of deposition (5). The topography of a ground moraine deposited by a continental glacier varies from a level to gently undulating surface with relief less than $20 \mathrm{feet}(32)$. In the ground moraine of the Wisconsin age, there exists a gently undulating surface that is frequently termed a sag and swell type topography.

In order to compare the topography, roughness indexes were computed for about seven areas selected in each of the three substages of the Wisconsin ground moraine. The roughness index, which was modified after the work of Hook (18), shows the density of contour lines as measured on a topographic map.

The density of contour lines was found in the following manner. A grid was superimposed over a topographic map. It was first oriented north-south and east-west. The intersections of the grid lines with contour lines were counted. The grid was then rotated 45 degrees to a 
northeast-southwest, northwest-southeast orientation, and the intersections were counted again. The roughness index was computed as:

$$
R I=\frac{N \times M}{A \times 4} \times \frac{C I}{10}
$$

where $\mathrm{N}$ is the total number of intersections in all four directions, $M$ is the distance between grid lines in miles, A is the land area covered by the grid in square miles, 4 is a constant to obtain the average number of grid-contour crossings in one direction, and CI is the contour interval of the map. The original formula by Hook was developed for use with a 100-foot contour map. The original formula had 10 in place of $\frac{C I}{10}$. Table 5 shows that the average roughness indexes were $10.0,3.2$ and 4.2 for the Early Tazewe1l, Late Tazewell, and Cary areas respectively.

Pedological soil surveys were also used to compare topography. It can be seen in Appendix B that the pedological soils mapped in the Early Tazewell area are oriented around the natural drainage systems while the pedological soils mapped in the other areas are mainly oriented around the sag and swell topography. Table 2, Soil Series of the Wisconsin Drift Subsection, shows that the Early Tazewell area has less depression or sag topography and more sloping topography than either the Late Tazewell or Cary area.

\section{Regional Drainage}

Regional drainage pattern gives a clue to the general porosity of the region, the dip and type of rock if rock is present, and the relative depth of unconsolidated material (15). Parvis has grouped the drainage patterns into six basic patterns (32). These are dendritic, trellis, parallel, radial, annular, and rectangular. Dendritic drainage patterns are normally formed by streams flowing in horizontal homogenous material. 


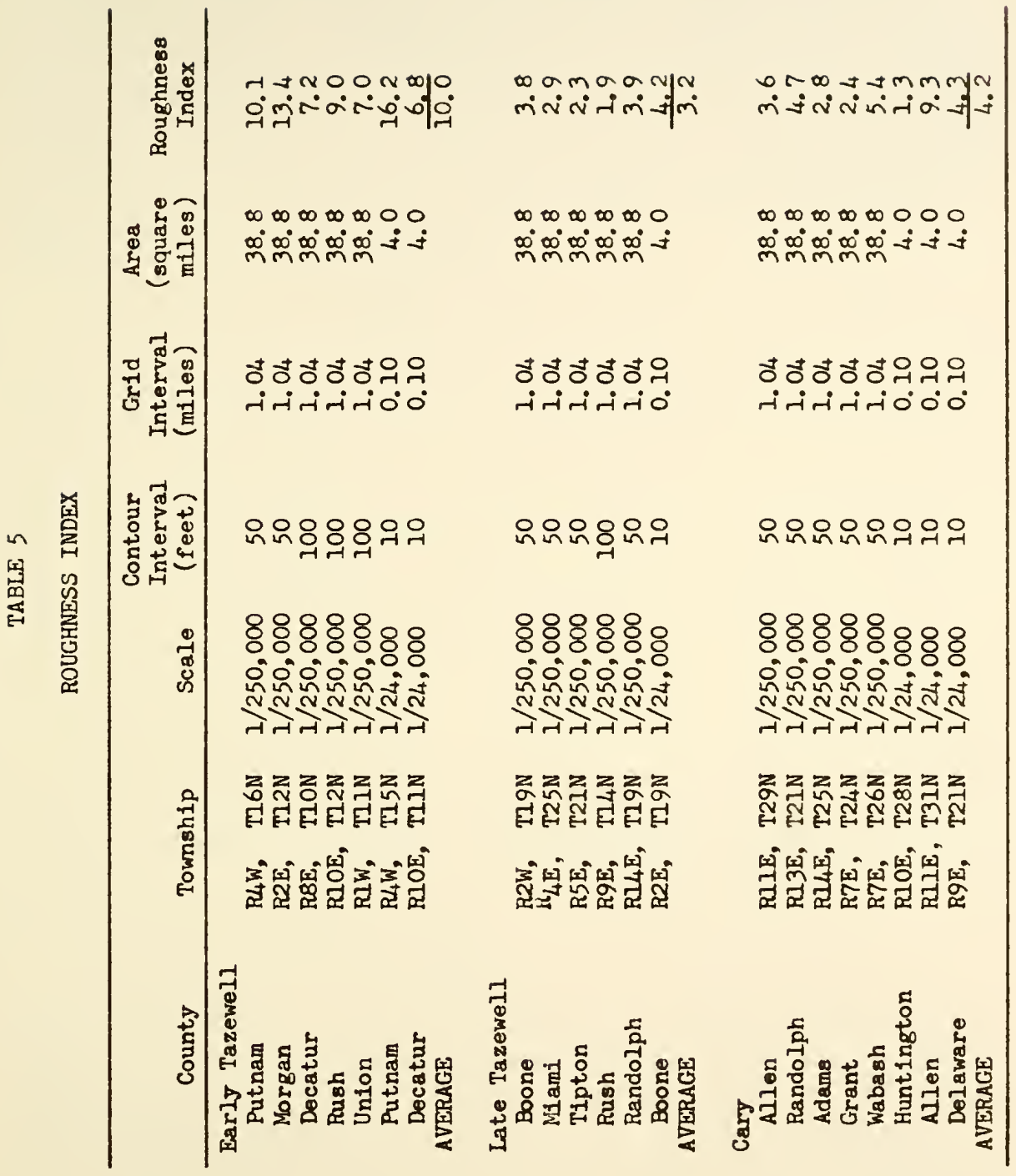


Trellis patterns develop in folded rocks while parallel drainage occurs in materials exhibiting a regional slope. The radial drainage pattern is associated with a peak or basin, and the annular drainage pattern is associated with a dome. Streams flowing in rock joints produce the rectangular drainage pattern. The regional drainage in the Wisconsin ground moraine is a modified form of dendritic pattern (5). The drainage pattern may show some parallelism due to regional slope or it may show some rectangularism due to underlying bedrock.

The density of the drainage pattern is a measure of the porosity of the material if other factors such as age and regional slope are the same. Because the Early Tazewell soils are reported to be better drained than the other areas of the Wisconsin Drift Subsection (9), it would seem reasonable that the drainage density would be greater in the Early Tazewell area. Also, because the Early Tazewell area has less depression soll (9), it should have less man-made drainage than either the Cary or the Late Tazewell areas.

As the Early Tazewell and Late Tazewell areas are of about the same age and are composed of material of about the same porosity, the difference in drainage density is probably due to regional slope. The slope of the major streams in an area is a measure of the regional slope.

The drainage density was computed from measurerents taken on the county drainage maps (1) which were prepared from aerial photography at a scale of $1 / 20,000$. Drainage density is the number of miles of drainage lines visible on photographs at a scale of $1 / 20,000$ per square mile of area. Drainage densities were measured in 43 sample areas of one square mile each selected throughout the Wisconsin Drift Subsection. The length 
of man-made drainage was delineated and measured directly on airphoto mosaics of the six sample areas shown in figure 6. The slopes of 15 major streams were measured from 1/250,000 topographic maps.

As shown in table 6, the average drainage densities of the Early Tazewell, Late Tazewell, and Cary areas were $6.1,2.8$, and 2.3 miles per square mile respectively.

Table 7 shows that on the average $4.6,24.8$, and 31.2 percent of the drainage is man-made in the Early Tazewell, Late Tazewell, and Cary areas respectively.

The average slope of the major streams was found to be $12.0,8.1$, and 3. 2 feet per mile for the Early Tazewell, Late Tazewell, and Cary area respectively. This is shown in table 8.

Because the depth of bedrock is generally less than 50 feet (see figure 4), the steep stream gradient has caused many of the major streams to cut down into the bedrock in the Early Tazewell area. This causes the regional dendritic drainage pattern to show some rectangularity, Also, the regional slope has caused the drainage pattern in the Early Tazewell to show some parallelism. The major streams in the Early Tazewell area are generally oriented in a southwest-northeast direction and are perpendicular to the contours as shown in figure 12.

\section{Local Erosion}

Erosional festures often reveal information concerning soil texture and depth (15). The erosional features may be subdivided into the processes which formed them. Erosional features may be formed by water, wind, ice, gravity, and thermal action (26). Water action creates gullies and rills which are probably the most important erosional features in the 


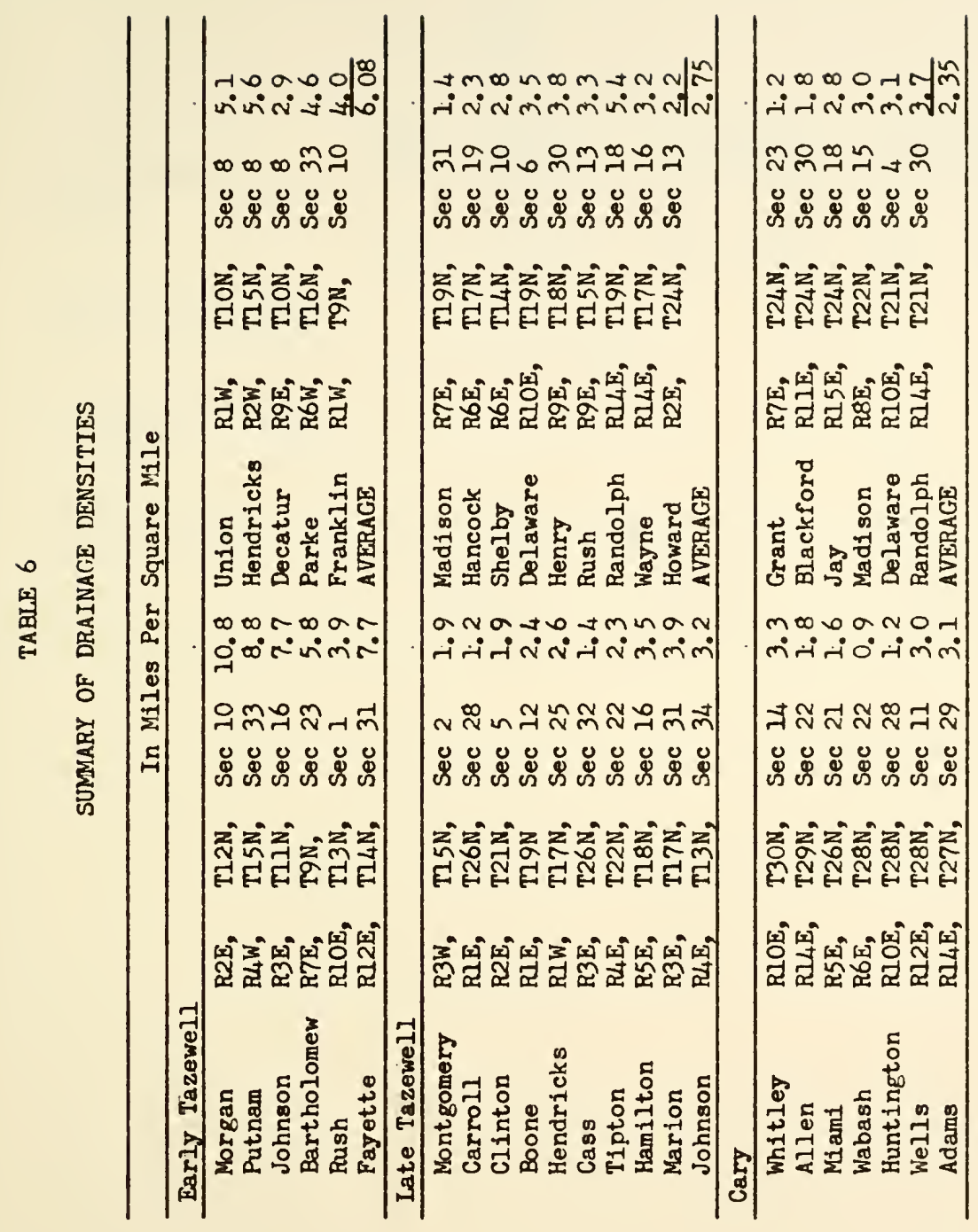


TABLE 7

PERCENT MAN-MADE DRAINAGE

\begin{tabular}{|c|c|c|c|c|c|c|}
\hline \multirow[b]{2}{*}{ Element } & \multicolumn{2}{|c|}{ Early Tazewell } & \multicolumn{2}{|c|}{ Late Tazewell } & \multicolumn{2}{|c|}{ Cary } \\
\hline & Rush & Putnam & Boone & Tipton & Grant & Whitley \\
\hline Location & $\begin{array}{l}\text { RIOE } \\
\text { TI2N }\end{array}$ & $\begin{array}{l}\mathrm{R} 4 \mathrm{~W} \\
\mathrm{~T} 15 \mathrm{~N}\end{array}$ & $\begin{array}{l}\text { R2W } \\
\text { T19N }\end{array}$ & $\begin{array}{l}\text { RuE } \\
\text { T2IN }\end{array}$ & $\begin{array}{l}\mathrm{R} 7 \mathrm{E} \\
\mathrm{T} 24 \mathrm{~N}\end{array}$ & $\begin{array}{l}\text { RIOE } \\
\text { T3ON }\end{array}$ \\
\hline $\begin{array}{l}\text { Density of Drainage } \\
\text { in miles/sq mile }\end{array}$ & 5.1 & 6.6 & 3.9 & 3.1 & 1.6 & 4.2 \\
\hline $\begin{array}{l}\text { Density of man-made } \\
\text { drainage in miles/ } \\
\text { sq mile }\end{array}$ & 0.30 & 0.22 & 0.85 & 0.86 & 0.74 & 0.68 \\
\hline $\begin{array}{l}\text { Percentage of man- } \\
\text { made drainage }\end{array}$ & 5.9 & 3.3 & 21.8 & 27.7 & 46.2 & 16.2 \\
\hline Average & & & 24. & & 31. & \\
\hline
\end{tabular}


TABLE 8

SLOPE OF MAJOR STREAMS

\begin{tabular}{|c|c|c|}
\hline Area & River & $\begin{array}{l}\text { Slope in } \\
\text { feet per mile }\end{array}$ \\
\hline $\begin{array}{l}\text { Early Tazewell } \\
\text { Putnam Co. } \\
\text { Hendricks Co. } \\
\text { Morgan Co. } \\
\text { Decatur Co. } \\
\text { Rush Co. } \\
\text { AVERAGE }\end{array}$ & $\begin{array}{l}\text { Clear Creek } \\
\text { West Fork Mill Creek } \\
\text { White Lick Creek } \\
\text { Clifty Creek } \\
\text { Little Flat Rock River }\end{array}$ & $\begin{array}{r}14.7 \\
11.1 \\
8.8 \\
14.3 \\
11.1 \\
12.0\end{array}$ \\
\hline $\begin{array}{l}\text { Late Tazewell } \\
\text { Boone Co. } \\
\text { Hamilton Co. } \\
\text { Tipton Co. } \\
\text { Madison Co. } \\
\text { Cass Co. } \\
\text { Henry Co. } \\
\text { Randolph Co. } \\
\text { AVERAGE }\end{array}$ & $\begin{array}{l}\text { Spring Creek } \\
\text { Little Cicero Creek } \\
\text { Prairie Creek } \\
\text { Big Kilbuck Creek } \\
\text { Deer Creek } \\
\text { Bill Creek } \\
\text { West Fork White River }\end{array}$ & $\begin{array}{r}13.2 \\
8.1 \\
7.1 \\
3.9 \\
6.5 \\
11.4 \\
6.1 \\
8.1\end{array}$ \\
\hline $\begin{array}{l}\text { Cary } \\
\text { Adams Co. } \\
\text { Wells Co. } \\
\text { Grant Co. } \\
\text { AVERAGE }\end{array}$ & $\begin{array}{l}\text { St. Marys RIver } \\
\text { Wabash River } \\
\text { Mississinewa River }\end{array}$ & $\begin{array}{l}1.2 \\
2.8 \\
5.6 \\
3.2\end{array}$ \\
\hline
\end{tabular}




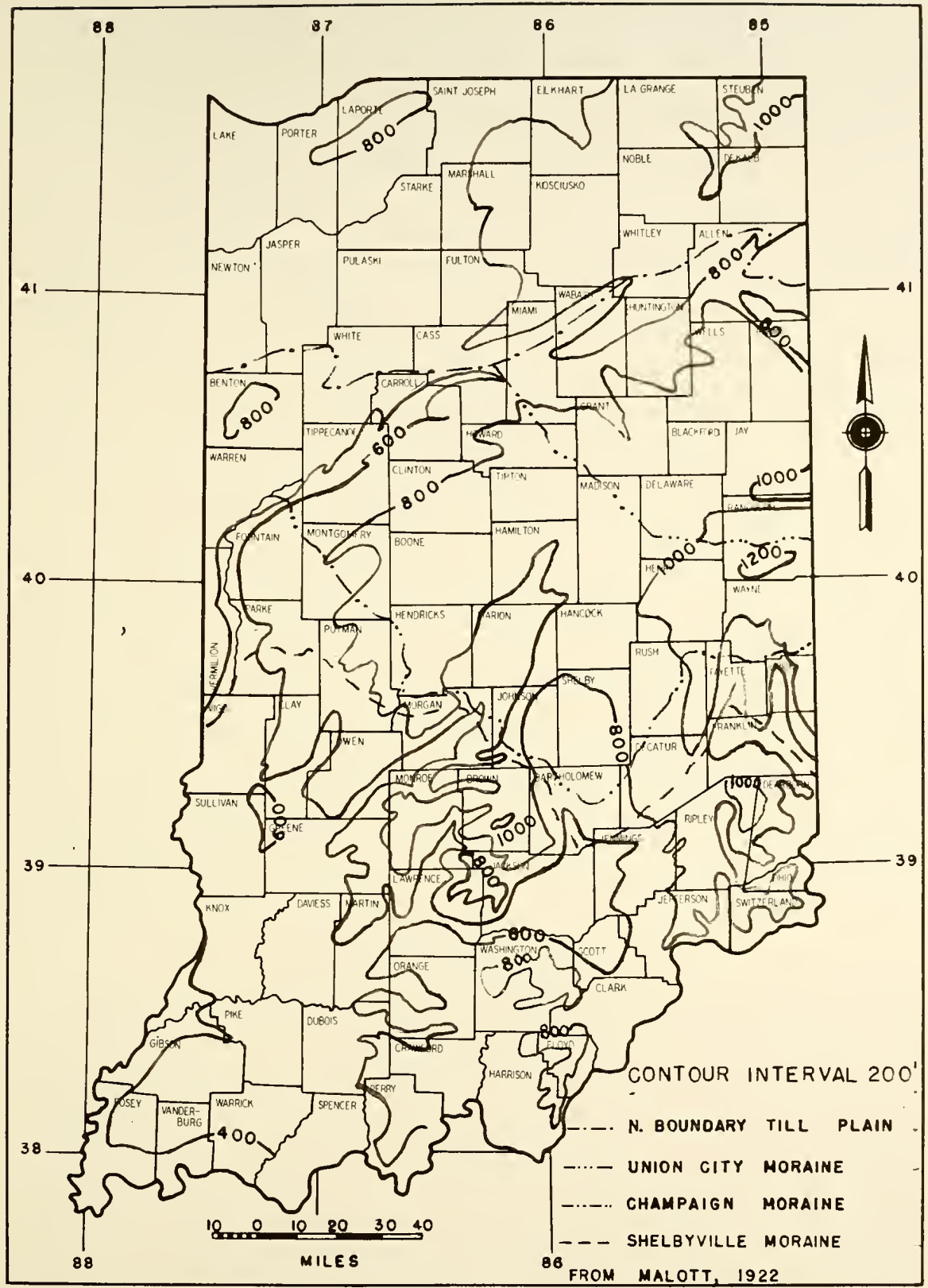

Figure 12. Topographic Map of Indiona. 
ground moraine. There are three basic gully characteristics which are associated with three major soll textural groups. These are as follows: granular soils with some cohesion develop sharp V-shaped gullies having a short steep gradient; non-granular, cohesive soils produce a broad softly rounded saucer-shaped gully cross-section with a low gradient; and, loess and sand-clay soils exhibit a gully whose cross-section is U-shaped with a short, low-gradient and has a bowl-shaped end (15).

Mosaics and stereo pairs covering the six sample areas were studied in detail in an attempt to identify local erosion features which would distinguish the substages of the Wisconsin ground moraine.

In the Wisconsin ground moraine, erosion is generally not severe. The Early Tazewell area does show more gully erosion because of the regional slope. The gullies tend to be more deeply entrenched than in the remainder of the Wisconsin ground moraine. Also, because of the loess cover of 18 to 40 inches, the gullies in the Early Tazewell area usually have a light fringe caused by rill gullies. This can be seen in the stereo pairs for the pedological soil maps in Putnam and Rush Counties in Appendix B, figures $B-1$ and $B-2$.

\section{Photo Gray Tone}

Objects are observed on black and white photographs in tones of gray. The photographic tone is of great importance in soil interpretation; however, it may be misleading at times. Tones of photographic images are influenced by many factors. These factors may be grouped as technical factors or natural factors. The technical factorsinclude variation in materials, equipment, exposures, and processing. Natural variables include atmospheric haze and cloud cover, soil color and moisture content, vegetation type and density, and climate. 
The Wisconsin ground moraine is characterized by a mottled tone. This is directly related to the sag and swell topography (6). The contrast in tone is not completely due to soil color but also moisture content. The depression soils have a higher moisture content which results in a darker color. Altschaeffl (3) in a study of the effects of natural variables on aerial photo gray tones found that 30 to 60 percent of the variation in gray tones was due to variations in soil moisture content. Mosaics and stereo coverage of the six sample areas shown in figure 6 were studied in an attempt to distinguish the Wisconsin substage by photo tones.

An explanation of the relationship between the mottled photo tone and the sag and swell topography of the Wisconsin ground moraine became evident. As shown in figure 13, the depression soils irrespective of age tend to develop a thick $A_{1}$ horizon while sloping soils develop in a thin $A_{1}$ horizon. When the ground is plowed the light-colored $A_{2}$ horizon is undisturbed in the basins while the surface soil on the rises is a mixture of the dark-colored $A_{1}$ horizon and the light-colored $A_{2}$ horizon. As the mottled tone is related to the topography, the percent of dark area in each substage would be about the same as the percent of the depression soils mapped in each area. As shown in table 2, the percent of depression soils is 11.2, 27.5, and 30.8 for the Early Tazewell, Late Tazewell, and Cary areas respectively.

In the Early Tazewell area the loess cover has caused the mottled photo tone to be slight and subtle. Because of the more mature natural drainage in the Early Tazewell substage, the dark areas have been connected to the drainage network and converted into long narrow swales. As the 


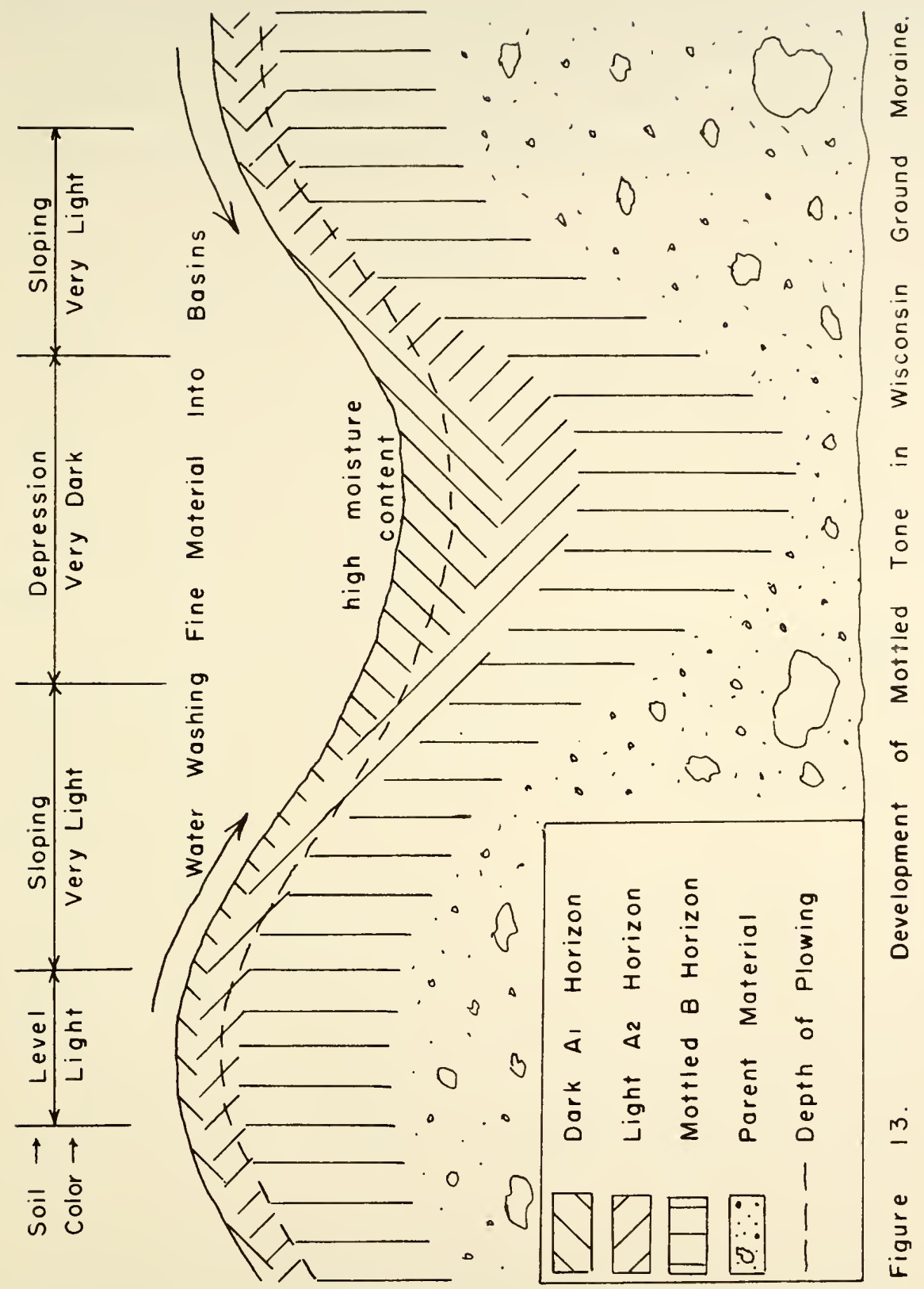


Late Tazewell area does not have a thick loess cover, the contrast between the dark-colored and light-colored soils tends to be sharper than in the Early Tazewell area. As shown in figures B-5 and B-6 of Appendix B, the photo tone of the Cary area can be described as fine-textured mottled tone.

\section{Vegetation}

Areas having the same natural vegetation are likely to contain the same soil. In California, a survey of a wild land area of fifty square miles showed that nearly 80 percent of the major soil boundaries corresponded with vegetation boundaries visible on aerial photographs (5).

A dense vegetation will obscure a major portion of the soil details. Tone change may be due to changes in vegetation and as a result the tones appear to stop at field boundaries (3).

As certain vegetation is more adaptable to certain soils, the type of vegetation may be helpful in distinguishing the substages of the Wisconsin ground moraine. Corn prefers dark-colored soils while small grain prefers light-colored soils $(44,47,49)$. On clayey soils more hay is usually grown $(9,46)$.

The percent of area covered by the various types of vegetation was determined for each substage. This was accomplished by averaging the values for counties which were almost entirely within one substage. These values were obtained from Agricultural Experiment Station Bulletin 628 (34).

The mosaics and stereo pairs of the six sample areas shown in figure 6 were then studied in an attempt to identify the various types of vegetation.

Table 9 shows types of vegetation in percentages of the total farm land for the three substages of the Wisconsin ground moraine. It can be 


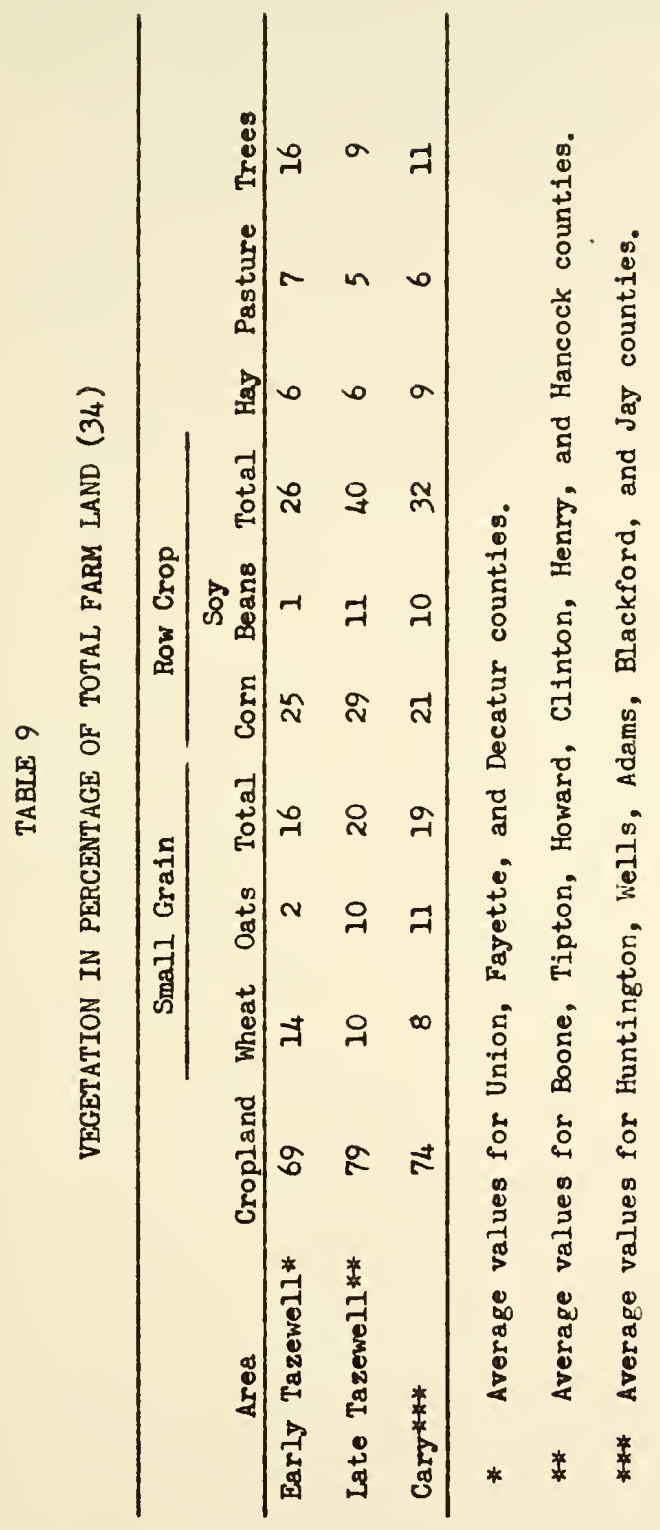


seen that the Early Tazewell area has the largest percent of trees, the Late Tazewell area has the largest percent cropland, and the Cary area has the largest percent of hay land.

A study of the photographs of the six sample areas indicated that small grain crops, row crops, and hay crops could not generally be distinguished. As a result crop vegetation cannot be used to distinguish the substages in the Wisconsin ground moraine.

The trees in the Early Tazewell area are usually along the deeper gullies while in the Late Tazewell and Cary areas they are usually in rectangular shaped tree lots.

\section{Cultural Features}

Cultural features may indicate land form and parent material. A regular pattern of fields and roads indicates a plain with little relif (15). In humid areas dead furrows, tile drainage, and field ditches indicate internal soil drainage conditions (15).

In the Cary area, the average field size is smaller (9), farms are smaller (34), and the land is less favorable for farming (9) than in the remainder of the Wisconsin Drift Subsection.

The number of farmsteads and fields per square mile were counted on mosaics of 17 sample areas in the Wisconsin Drift Subsection. Farmsteads were considered to be any group of buildings that appeared to be a headquarters for a farming operation. The average field sizes were measured by planimeter in the six sample areas shown in figure 6. The average land value was obtained from Agricultural Experiment Station Bulletin 628 (34).

As shown in table 10 the average number of farmsteads were 5.8, 6.7, and 7.6 per square mile for the Early Tazewell, Late Tazewell, and Cary 


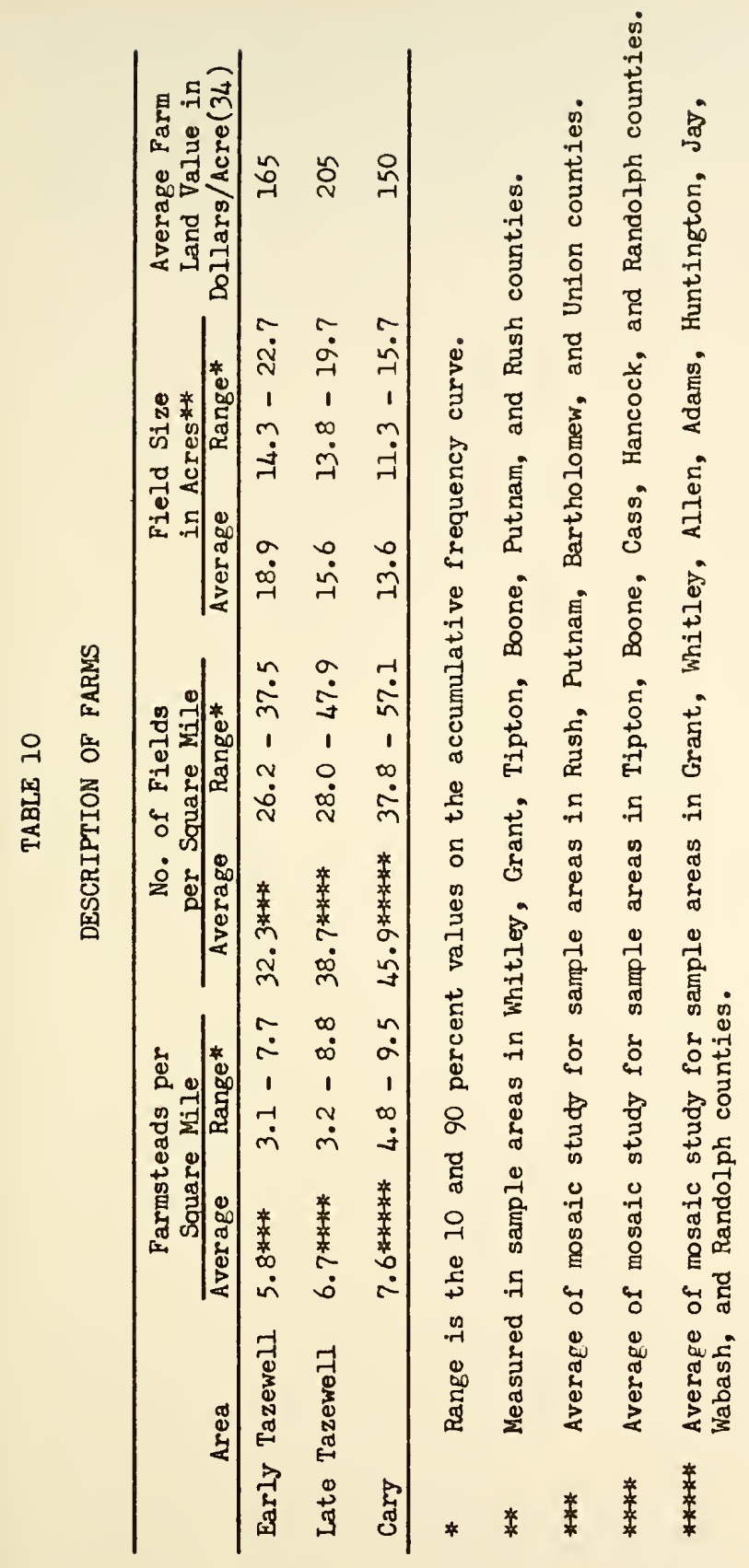


areas respectively. Table 10 also shows that the Cary area has the smallest average field size and lowest farm land value. The average field size was 18.9, 15.6, and 13.6 acres for the Early Tazewell, Late Tazewell, and Cary areas respectively. 
CHAPTER IV

DESCRIPTION OF THE DETAILED AIRPHOTO PATTERNS

OF THE WISCONSIN SUBSTAGES

The following sections describe the airphoto patterns for the Early Tazewell, Late Tazewell, and Cary areas of the Wisconsin ground moraine. As the patterns are affected by such natural factors as moisture, vegetation, and season, some variations to the typical patterns are also shown.

\section{Early Tazewell Area}

Figures $14 \mathrm{a}$ and $14 \mathrm{c}$ are typical airphotos representing the glacial ground moraine of the Early Tazewell substage. The topography varies from undulating to rolling due to stream dissection. The roughness index ranges from seven to 16 with an average of about ten. The regional drainage pattern is medium textured dendritic but many of the major streams show rock control as shown in figure $14 \mathrm{a}$ by the arrow. The drainage systems extend to nearly all basin areas and have caused the depressions to become long and narrow. The drainage density ranges from three to eleven miles per square mile with about six miles per square mile average. Only about five percent of the drainage is man-made. A light gray fringe can be seen around the gullies which are entrenched into the upland. The gully cross-section is saucer-shaped on the outer edges but tends to show a Ushaped center. The mottled tone is somewhat subdued and the dark depression soils cover only about 11 percent of the total area. Many of the 


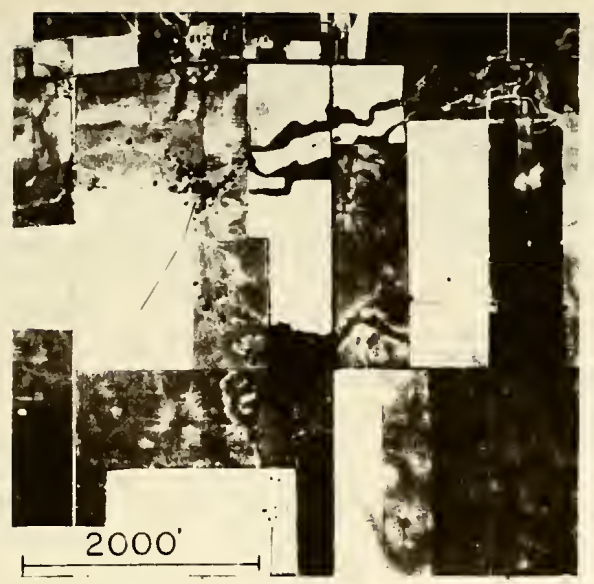

(a)

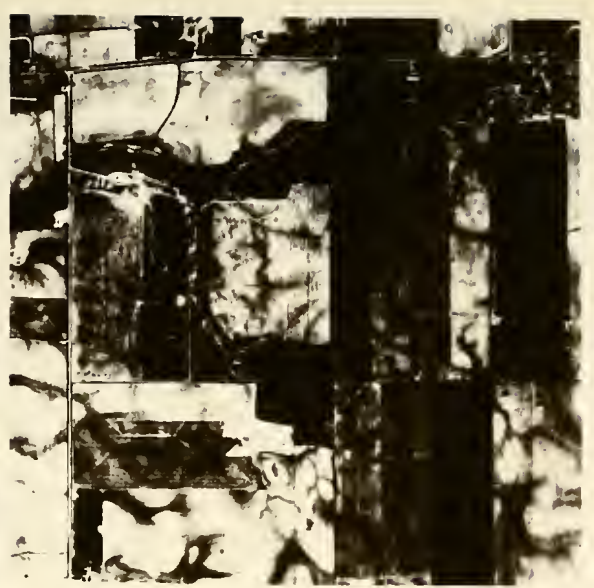

(b)

\section{RUSH COUNTY, RIOE, TI2N, SEC. 18}

РнОтО FM-2A-38, 6-20-40 PHOTO FM-IR-I3I, 5-24-56

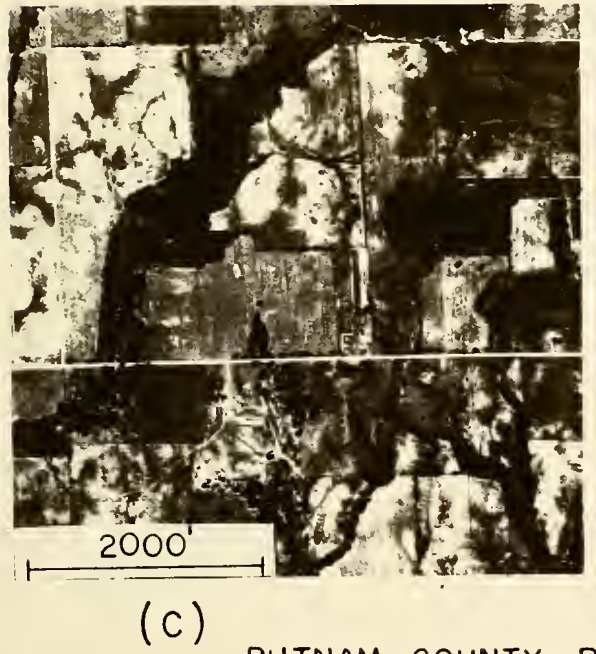

PUTNAM COUNTY, R4W, TI5N, SEC. 29

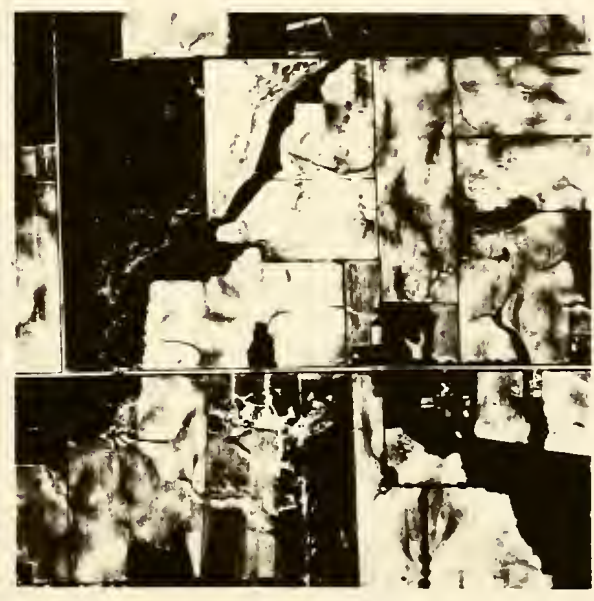

(d)

PHOTO BWL-4-62, 8-10-39 PHOTO BWL-IV-97, 6-18-58

Figure 14. Typical Early Tazewell Airphoto Patterns and Variotions. 
larger gullies control the shape of the flelds and location of roads. As the side slope of the deeper gullies are steep, they are not farmed and are left in trees. The farms are large in this area and there are only about six farmsteads per square mile. The average fleld size is about 19 acres.

Figures $14 \mathrm{~b}$ and $14 \mathrm{~d}$ cover the same areas as figures $14 \mathrm{a}$ and $14 \mathrm{c}$ respectively. There appears to be a greater contrast in photo tone due to greater moisture content of the areas in figures $14 \mathrm{~b}$ and $14 \mathrm{~d}$. A comparison of the field in the upper left corner of figures $14 \mathrm{c}$ and $14 \mathrm{~d}$ will show the affect of vegetation on soil tones. The soil tone is almost obscured by vegetation in figure $14 d$.

\section{Late Tazewell Area}

Figure 15 shows airphotos of the ground moraine of the Late Tazewell substage in Tipton and Boone Counties. The pattern shown in figure 15a has been used as the "classic" example of Wisconsin ground moralne.

The topography is that of a gently undulating plain. The roughness index ranges from two to four with an average of about three. The regional drainage pattern is coarse textured dendritic. The streams are not deeply entrenched and usually flow in a broad, saucer-shaped, low area. The drainage density ranges from one to five miles per square mile with about three miles per square mile average. About 25 percent of the drainage has been improved by man. The dark depression soils cover about 27 percent of the total area. Trees are sometimes left along the streams as the high water table makes the ground difficult to farm. There are about seven farmsteads per square mile and the average field size is about 16 acres. 


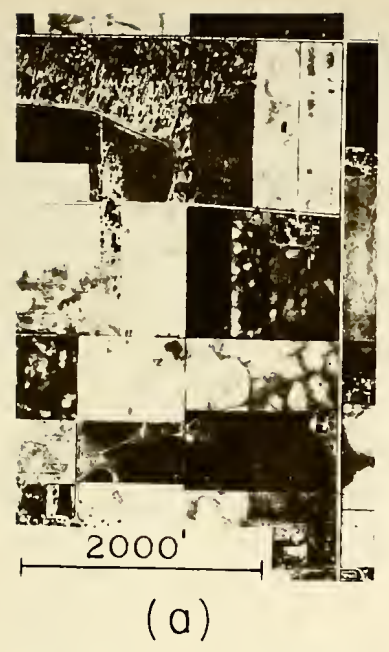

WHITLEY BFY-3-75, $10-22-38$

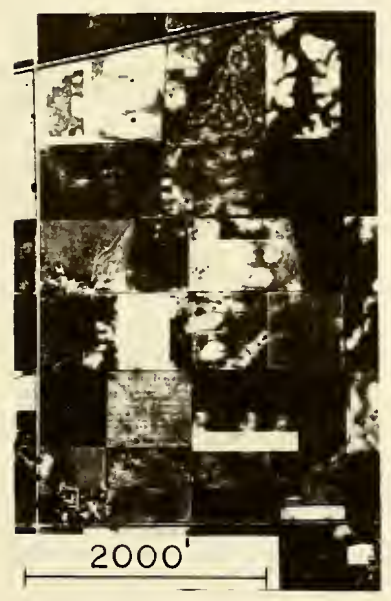

(d)

GRANT BFC-IB-84, 7-15-41

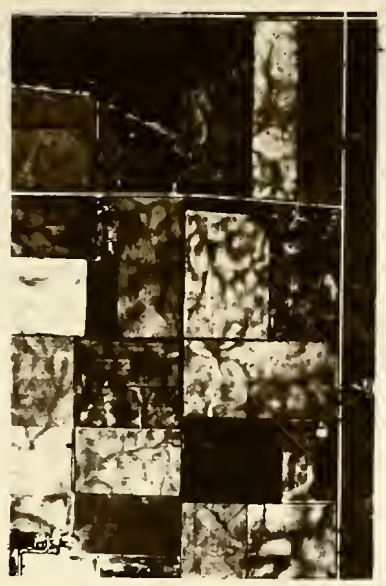

(b)

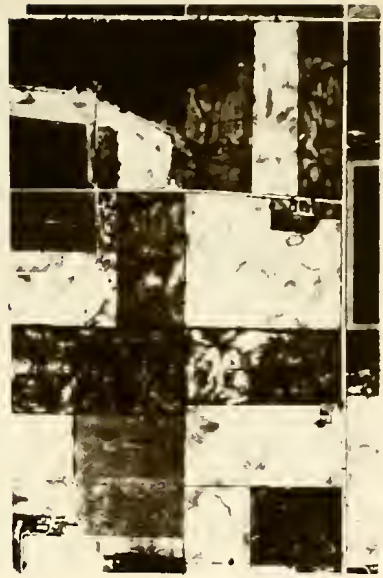

(C)

COUNTY, RIOE, T3ON, SEC. 18 BFY-2H-175, 7-7-5I

BFY-3T-8I, 6-20-57

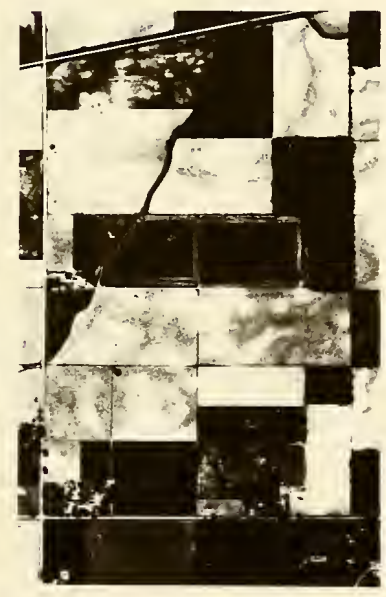

(e)

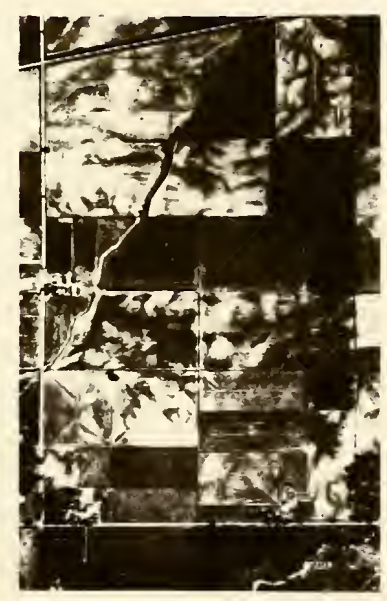

(f)

COUNTY, RI2E, T24N SEC. 21 $B F C-I R-63,6-10-56$ BFC-2R-11, 6-22-56

Figure 16. Typical Cary Airphoto Patterns and Variations. 
The parent material in figure $15 \mathrm{c}$ is more granular in texture than In figure 15a; therefore, the mottled photo tone is subdued. The light tones on the high topographic positions also imply coarse textured soils. Many of the basins in figure $15 \mathrm{c}$ have the appearance of inflltration basins in granular material.

A comparison of figures $15 \mathrm{a}$ and $15 \mathrm{c}$ with figure $15 \mathrm{~b}$ and $15 \mathrm{~d}$ respectively will show the seasonal effect on photo tones. Figures $15 \mathrm{a}$ and $15 \mathrm{c}$ were taken in June while $15 \mathrm{~b}$ and $15 \mathrm{~d}$ were taken in September and October. The photos taken in the fall show less contrast between the dark and light photo tones.

\section{Cary Area}

The topography of the Cary area is similar to the Late Tazewell area except the basins and rises are smaller and more numerous. The roughness index ranges from one to nine with an average of about four. The regional dendritic drainage pattern seldom shows rock control. The drainage density ranges from about one to four miles per square mile with an average of about two miles per square mile. Although about 30 percent of the drainage has been improved by man, many basins are undrained. Gull1es are few in number and are poorly developed. Those that exist usually have a shallow, saucer-shaped cross-section. The photo tone varies from a finely mottled photo tone as shown in figure $16 \mathrm{a}$ or finely mottled, spotted photo tone as shown in figure 16d. The dark depression soils cover about 30 percent of the area. Trees are usually found in rectangularshaped lots. The average field size is about 14 acres and there are about eight farmsteads per square mile. 


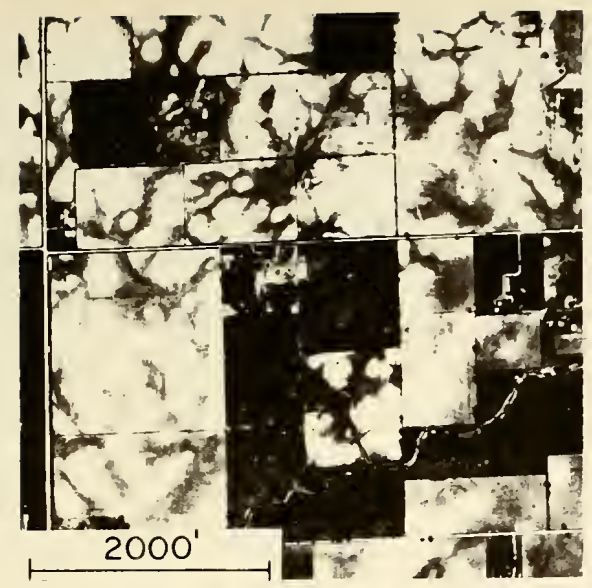

(a)

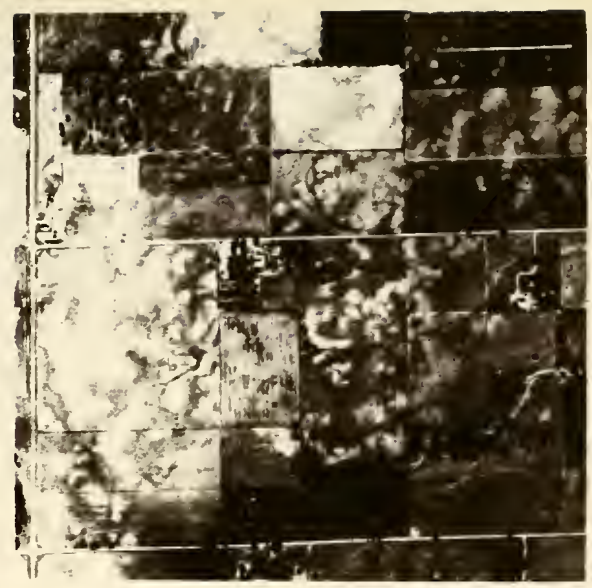

(b)

TIPTON COUNTY, R4E, T2IN, SEC. 30

PHOTO BWM-2-83, 6-5-39 PHOTO BWM-4R-103, 9-21-56

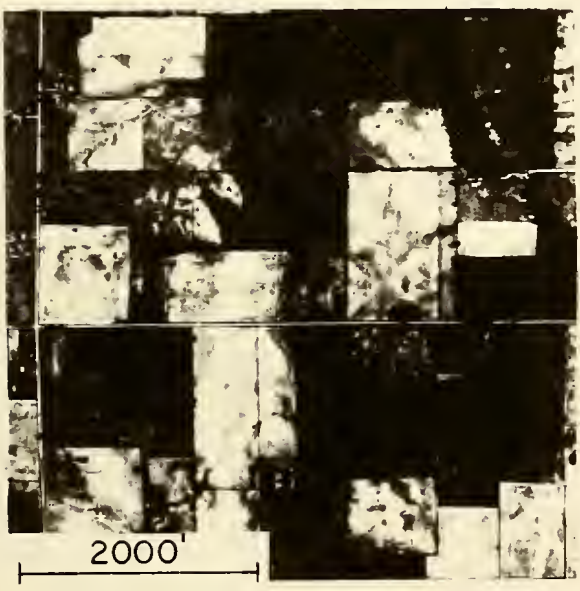

(c)

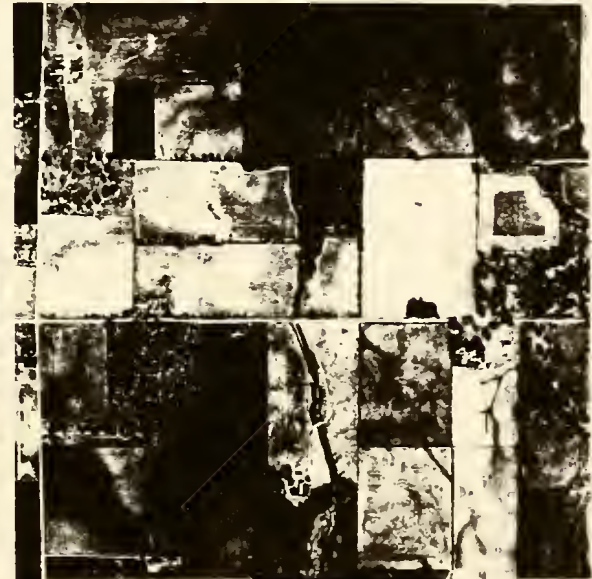

(d)

BOONE COUNTY, R2W, TI9N, SEC. 15

PHOTO BWE-5-28, 6-26-39 PHOTO BWE 2P 111810955

Figure 15. Typical Lote Tozewell Airphoto Patterns and Variotions. 
All of the photographs shown in figure 16 were taken in June or July except $16 a$ which was taken in October. Figures $16 \mathrm{c}$ and $16 \mathrm{f}$ were obtained when the soil had a high moisture content. It can be seen in figure 168 that the stream is larger and has a lighter color (due to 1ts muddy condition) than in either $16 \mathrm{~d}$ or $16 \mathrm{e}$. 


\section{CONCLUSIONS}

The following statements may be made concerning the classification of the Wisconsin ground moraine by airphoto interpretation.

1. The main engineering significance of the Early Tazewell area is its rolling to undulating topography and its silt with clay and sand parent material.

2. The main engineering significance of the Late Tazewell area is its level to gently undulating topography and its silt with sand parent material.

3. The main engineering significance of the Cary area is its level to gently undulating topography, its extensive man-made ditch system, and its clay with silt and sand parent material.

4. By interpretation of airphotos at a scele of $1 / 20,000$ it is usually possible to distinguish between the substages of the Wisconsin ground moraine in Indiana. 
BIBLIOGRAPHY 


\section{BIBLIOGRAPHY}

1. Airphoto Laboratory Staff, "Atlas of County Drainage Maps of Indiana," Joint Highway Research Project, Purdue University, 1959.

2. Agricultural Experiment Station, "Map of Indiana Soils," Purdue University, 1956.

3. Altschaeffl, A. G., "Effect of Soil Moisture and Other Natural Var1ables on Aerial Photo Gray Tones," MSCE Thesis, Purdue University, 1955.

4. Atwood, W. W., "The Physiographic Provinces of North America," Ginn and Company, Boston, 1940.

5. American Society of Photogrammetry, "Manual of Photographic Interpretation," The George Banta Company, Inc., Menasha, Wisconsin, 1960.

6. Belcher, D. J., Gregg, L. E., and Woods, K. B., "The Formation, Distribution and Engineering Characteristics of Soils," Highway Research Bulletin No. 10, Research Series No. 87, Purdue University, January 1943.

7. Bieber, C. L., "A Pleistocene Section Near Greencastle, Indiana," Indiana Acadeny of Sclence Proceedings, Volume 64, 1955.

8. Bruce, A. G. and Clarkeson, "Highway Design and Construction," International Textbook Company, Scranton, Pennsylvania, 1950.

9. Bushnell, T. M., "The Story of Indiana Soils," Purdue University, Agriculture Experiment Station, June 1944.

10. Emiliani, C., "Pleistocene Temperatures," Journal of Geology, Volume $63,1955$.

11. Fenneman, N. M., "Physiography of Eastern United States," McGraw-Hill Book Company, Inc., New York, 1938.

12. Flint, R. F., "Glacial and Pleistocene Geology," John Wiley and Sons, Inc., New York, 1957.

13. Flint, R. F., "Leaching of Carbonates in Glacial Drift and Loess as a Basis for Age Correlation," Journal of Geology, Volume 57, 1949.

14. Flint, R. F., "Rates of Advance and Retreat of the Margin of the Late Wisconsin Ice Sheet," American Journal of Science, Volume 253, 1955. 


\section{BIBLIOGRAPHY (continued)}

15. Frost, R. E., "Interpretation of Soils and Rocks for Engineering Purposes," Joint Highway Research Project, Purdue University, 1953.

16. Gooding, A. M., Thorp, J., and Gamble, E., "Leached Clay-enriched Zones in Post-Sangamonian Drift in Southwestern Ohio and Southeastern Indiana," Bulletin of Geological Society of America, Volume 70, 1959.

17. Harrison, W., "Marginal Zones of Vanished Glaciers Reconstructed from the Proconsolidation Pressure Values of Overridden Silts," Journal of Geology, Volume 66, 1958.

18. Hook J. C., "The Quantification of Land Form Characteristics - a Roughness Index," Proceedings of the Indiana Acadeny of Sclence, Volume $68,1959$.

19. Hough, J. L., "Geology of the Great Lakes," University of Inlinois Press, 1958.

20. Hough, J. L., "Pleistocene Climate Records in a Pacific Ocean Core Sample," Journal of Geology, Volume 61, 1953.

21. Indiana Soil Survey and U. S. Department of Agriculture, "Key to Indiana Soils," November 1956.

22. Leighton, K. M., "The Classification of Wisconsin Glacial Stage of North Central United States," Journal of Geology, Volume 68, 1960.

23. Leighton, M. M., "Important Elements in the Classification of the Wisconsin Glacial Stage," Journal of Geology, Volume 66, 1958.

24. Leverett and Taylor, "Pleistocene of Indiana and Michigan and the History of the Great Lakes," U. S. Geological Survey Monographs, Volume LIII, 1915.

25. Lobeck, A. K., "Physiographic Diagram of North America," Columbia University, New York, 1950.

26. Lueder, D. R., "Aerial Photographic Interpretation," MeGraw-Hill Book Company, Inc., New York, 1959.

27. Malott, C. A., "Handbook of Indiana Ceology," Indiana Department of Conservation, 1922.

28. McLerran, J. H., "Engineering Use of Agricultural Soil Maps," State College of Washington, Pullman, Washington, 1954.

29. Michael, H. L., and others, "A Study of Highway Transportation in Indiana," Engineering Bulletin Series No. 98, Purdue University, 1959. 


\section{BIBLIOGRAPHY (continued)}

30. Miles, R. D., "Procedures for Making Preliminary Soil and Drainage Surveys from Aerial Photographs," MSCE Thesis, Purdue University, 1951.

31. Moore, R. C., "Historical Geology," McGraw-Hill Book Company, Inc., New York, 1958.

32. Parvis, M., "Regional Drainage Patterns of Indiana," Reprint No. 35, Engineering Experiment Station, Purdue University, 1948.

33. Portland Cement Association, "PCA Soil Primer," Chicago, Illinois, 1956.

34. Robertson, L. S., Hicks, J. W., and Young, E. C., "Types of Farming in Indiana," Agricultural Experiment Station Bulletin 628, Purdue University, 1955.

35. Ruthe, R. V., "Reclassification and Correlation of the Glacial Drifts of Northwestern Iowa and Adjacent Areas," Geological Society of America, Volume 61, 1950.

36. Ruthe, R. V., Rubin, M., and Scholtes, W., "Late Pleistocene Radiocarbon Chronology in Iowa," American Joumal of Science, Volume 255, 1957.

37. Suess, H. E., "U. S. Geological Survey Radiocarbon Dates," Science, Volume 120, 1954 .

38. Terrel, R. L., "A Classification and Glossary of Iand Forms and Parent Materials," MSCE Thesis, Purdue University, 1961.

39. Thornbury, W. D., "Principles of Geomorphology," John Villey and Sons, Inc., New York, 1954.

40. Ulrich, H. P., "Wisconsin Moraines as a Source of Loess in Soil Formation in Fayette and Union Counties, "Proceedings of the Indiana Academy of Science, Volume 68, 1959.

41. U. S. Department of Agriculture, "Atlas of American Agriculture," 1936.

42. U. S. Department of Agriculture, "Morphology and Composition of Some Soils of the Miami Family and the Miami Catena," Technical Bulletin No. $834,1942$.

43. U. S. Department of Agriculture, "Soils and Men," Yearbook of Agriculture, 1938.

44. U. S. Department of Agriculture, "Soil Survey of Blackford County. Indiana," Number 32, Series 1928. 


\section{BIBLIOGRAPHY (continued)}

45. U. S. Department of Agriculture, "Soll Survey of Boone County, Indians," Field Operations of the Bureau of So1ls, 1912.

46. U. S. Department of Agriculture, "Soil Survey of Grant County, Indiana," Field Operations of the Bureau of Solls, 1915.

47. U. S, Department of Agriculture, "Soil Survey of Hancock County, Indiana," Number 23, Series 1925.

48. U. S. Department of Agriculture, "Soil Survey of Putnam County, Indiana," Number 27, Series 1925.

49. U. S. Department of Agriculture, "Soil Survey of Rush County, Indiana," Number 44, Series 1930.

50. U. S. Department of Agriculture, "Soil Survey of Tipton County, Indiana," Field Operations of the Bureau of Solls, 1912.

51. Wayne, W. J., "Glacial Geology of Indiana," Indiana Department of Conservation, 1958.

52. Wayne, W. J., "Thickness of Drift and Bedrock Physiography of Indiana North of the Wisconsin Glacial Boundary," Indiana Department of Conservation, Geological Survey Progress Report No. 7, 1956.

53. Wayne, W. J., "Wisconsin Stratigraphy of Central and Eastern Indiana," Proceedings, of Indiana Academy of Science for 1953, Volume 63, 1954.

54. Woods, $\mathrm{K}_{0} \cdot \mathrm{B}_{*}$, "Hlghway Engineering Handbook," McGraw-Hill Book Company, Inc., 1960. 
APPENDIX A 
APPENDIX A

\section{GLACIAL LAND FORM TERMS \\ Modified After Terrel (38)}

DRUMLIN. A streamlined oval hill composed principally of glacial till which has its long axis parallel to the direction of glacial movement. They are rarely found singly but exist in great fields or swarms. ESKER. A relatively long, narrow, sinuous ridge composed of water-laid glacial-fluvial drift. They are considered to have been formed by streams of meltwater flowing off through crevasses and through tunnels in the bases of stagnant ice sheets.

KAME, A rounded to conical-shaped hill or irregular mound composed of water deposited glacial drift. The material is usually semi-stratified to unstratified sands and gravels. Most kames are considered to be icecontact features whose materials were laid down in contact with an ice surface.

KETTLE. A basin or cavity in glacial drift, created by the melting of a former mass of glacier ice that was wholly or partly buried in the drift. They may be irregular in plan, but most tend to be circular. They occur in stratified drift and less commonly in till.

LACUSTRINE PLAIN. An extremely flat area that once was the site of a lake that has since become extinct. Shore lines of the larger extinct lakes are marked by beaches, bars, and sand dunes. Lacustrine plains are 
generally underlain by clays and silts. Some are underlain by sands, and commonly grade from sands and gravels near the shore to finer materlals at the center.

MORAINE. An accumulation of glacial drift having a topographic form that was constructed directly by the ice, but having no relationship to the underlying surface. A moraine fo of coneiderable lateral extent and does not include minor features such as drumlins. Two general types of moraines are recognized: ground moraine and ridge moraine.

Ground moraine constitutes the accumulation of drift beneath the glacier and forms a surface of low relief which is lacking any linear, ridge-like features. The surface is generally flat (often called a till plain) to gently undulating and drift may be thick enough to obliterate any topographic expression underlying 1t, however in many cases, the moraine exists as a thin veneer over bedrock surface.

A ridge moraine is an all-inclusive term that is used to designate ang ridge-like morainic form as differentiated from ground moraine. The topographic expression varies considerably, those ridge moraines composed chiefly of coarse material often stand higher than those composed of clayey material. They are seldom continuous for great distances, but usually are segmented because of breaks made through them by drainage outlets or lack of material deposited in some places. OUTWASH PLAIN. A plain of low relief composed of glacial outwash material. It is usually produced by the merging of a series of outwash fans or aprons. As the term implies it is formed beyond the glacier itself. TILL PLAIN. A level or gently undulating land surface composed of glacial till resulting from regional deposition by ice, where complete burial 
of preglacial topography has taken place. In general, where the glacially deposited surface lacks conspicuous ridge-like form, it may be called ground moraine. 
APPENDIX B 


\section{APPENDIX B}

STEREOSCOPIC AIRPHOTO COVERAGE

WITH PEDOLOGICAL SOIL BOUNDARIES

\section{Location of areas}

$\begin{array}{llll}\text { Rush County } & \text { RIOE, TI2N } & \text { Putnam County } & \text { R4W, TI5N } \\ \text { Tipton County } & \text { R4E, T2IN } & \text { Boone County } & \text { R2W, TI9N } \\ \text { Whitley County } & \text { RIOE, T3ON } & \text { Grant County } & \text { R7E, T24N }\end{array}$

Legend

- - - Section lines.

\begin{tabular}{l|l}
18 & 17 \\
19 & 20
\end{tabular} Section corner with section numbers.

- - $^{-}$G2 Soil sample site with site number.

Pedological soil symbols

Rush and Putnam Counties

$$
\begin{aligned}
& \text { Rs - Russell } \\
& \text { Fn - Fincastle } \\
& \text { Bk - Brookston } \\
& \text { Gn - fluvial soll }
\end{aligned}
$$

Tipton and Boone Counties

$$
\begin{aligned}
& \text { Mi - Miami } \\
& C_{r} \text { - Crosby } \\
& \text { Bk - Brookston }
\end{aligned}
$$

Whitley and Grant Counties

$$
\begin{aligned}
& \text { St - St. Clair } \\
& \text { Na - Nappanee } \\
& B k \text { - Brookston } \\
& M \text { - muck }
\end{aligned}
$$




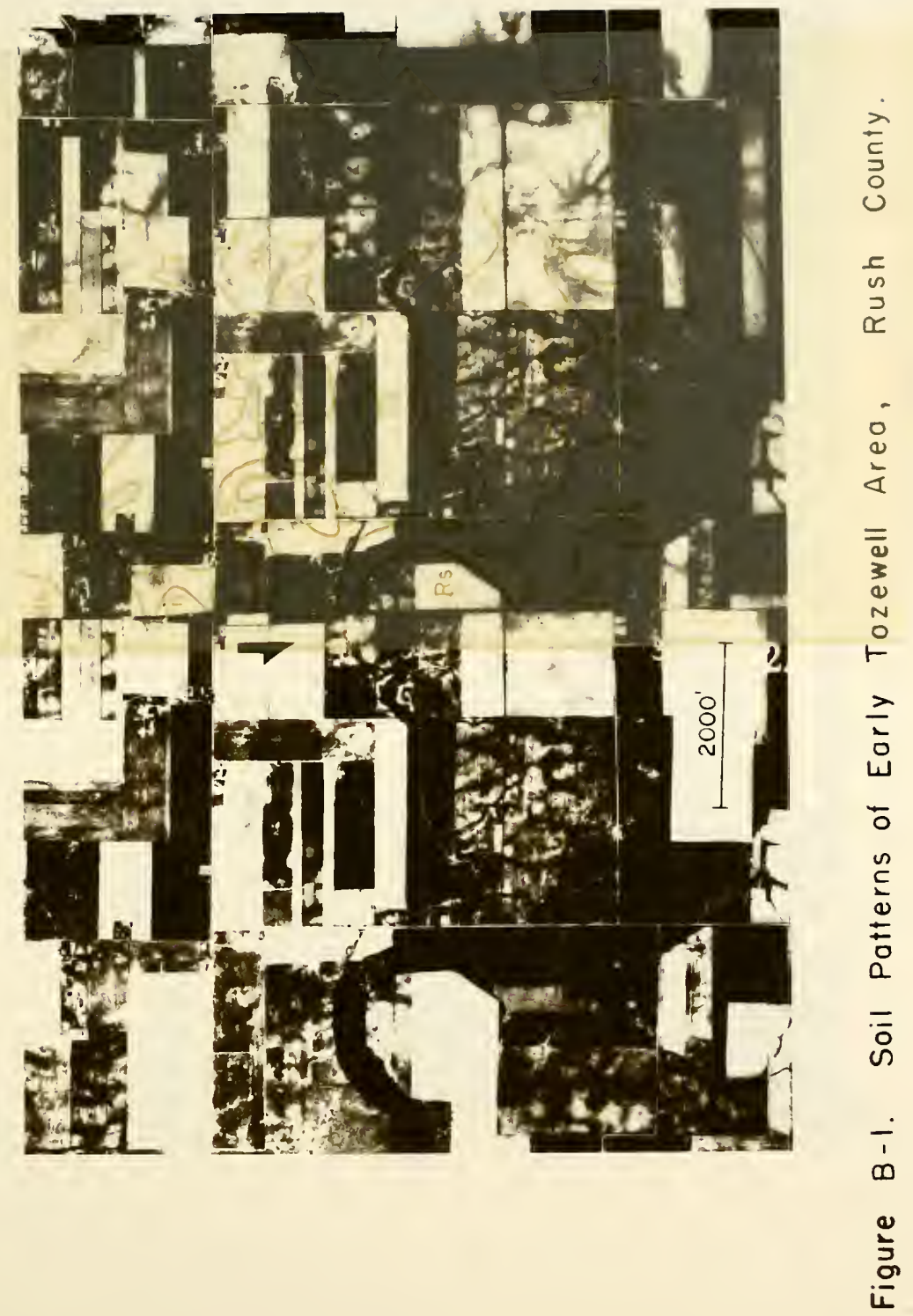




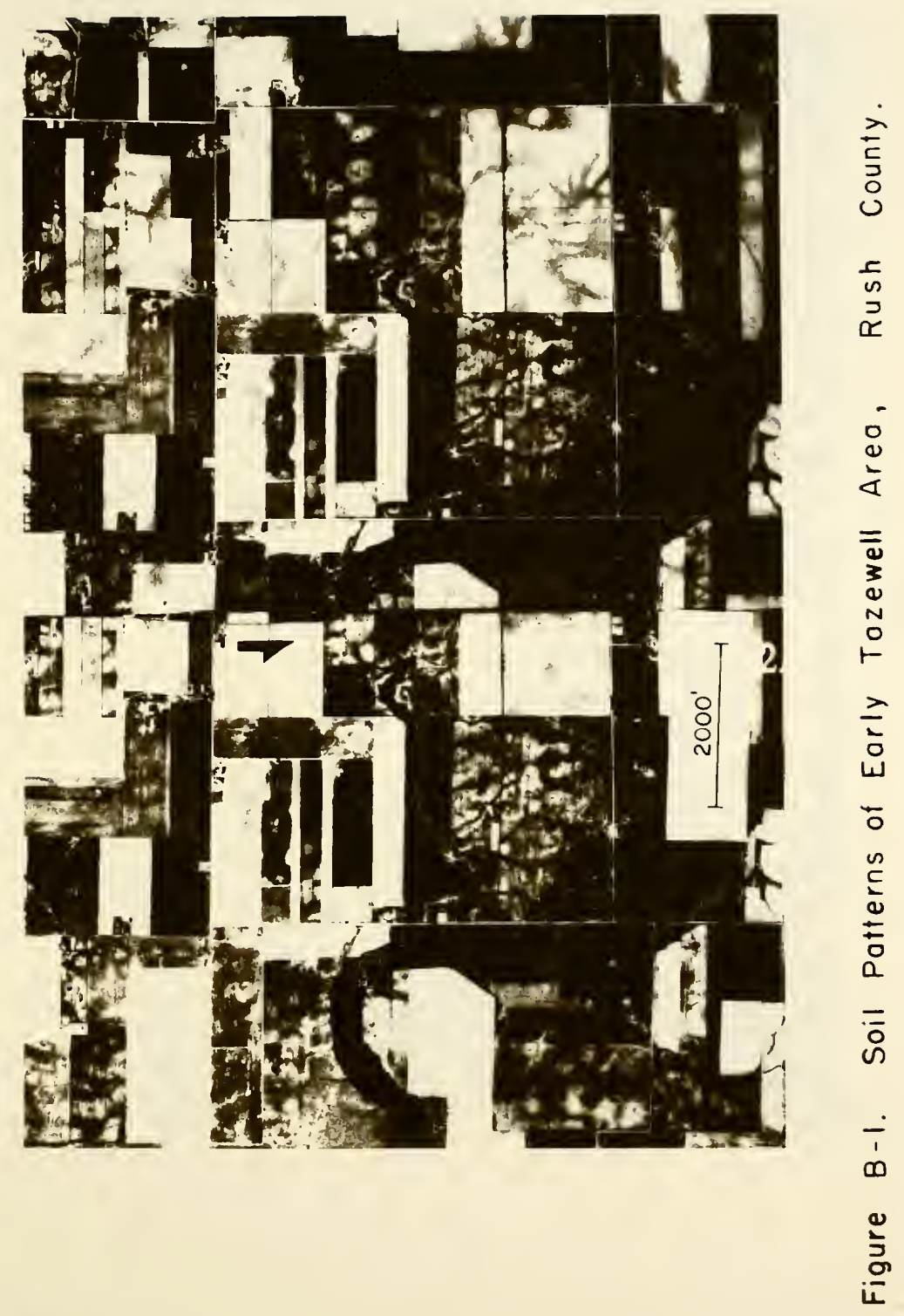




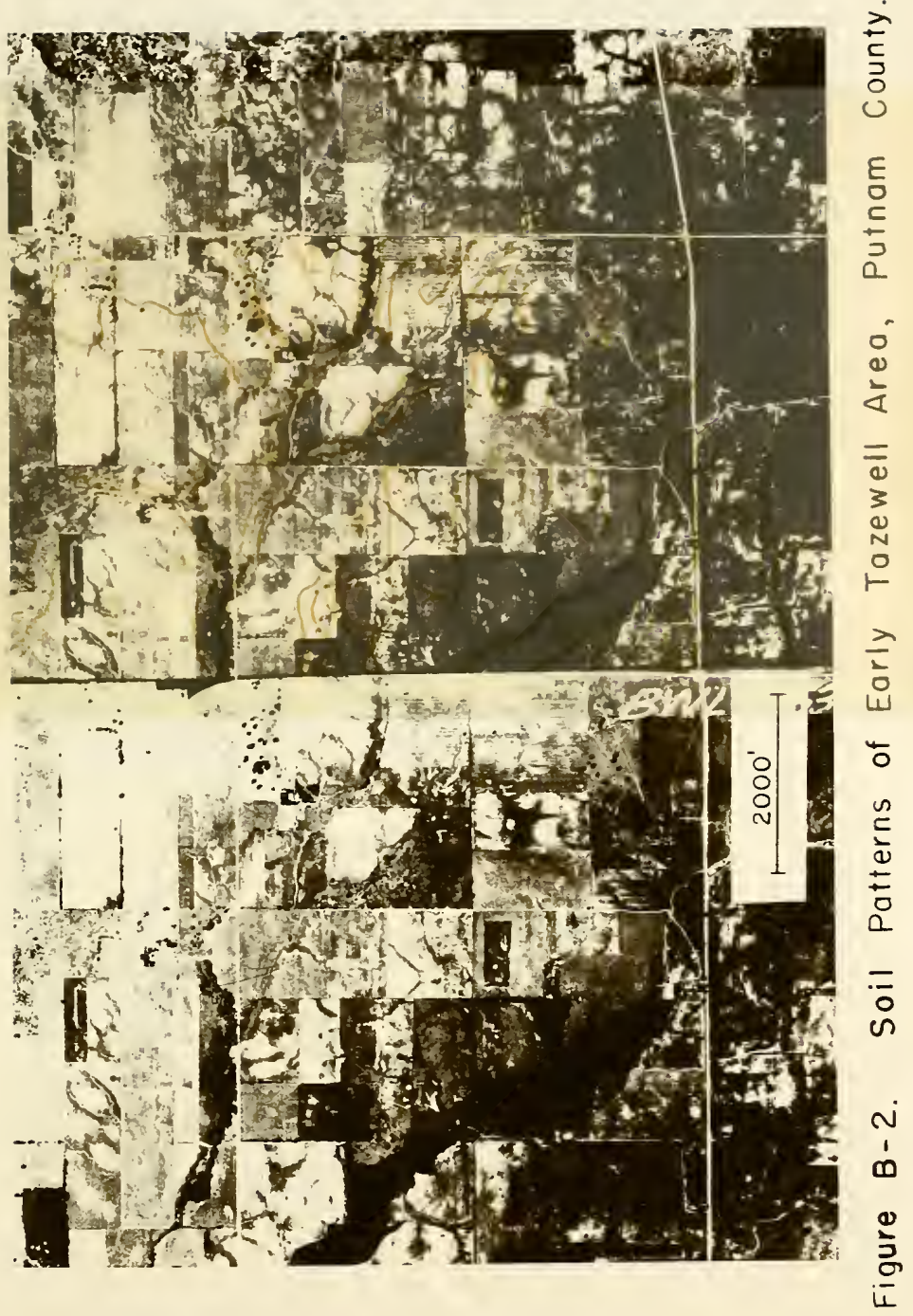




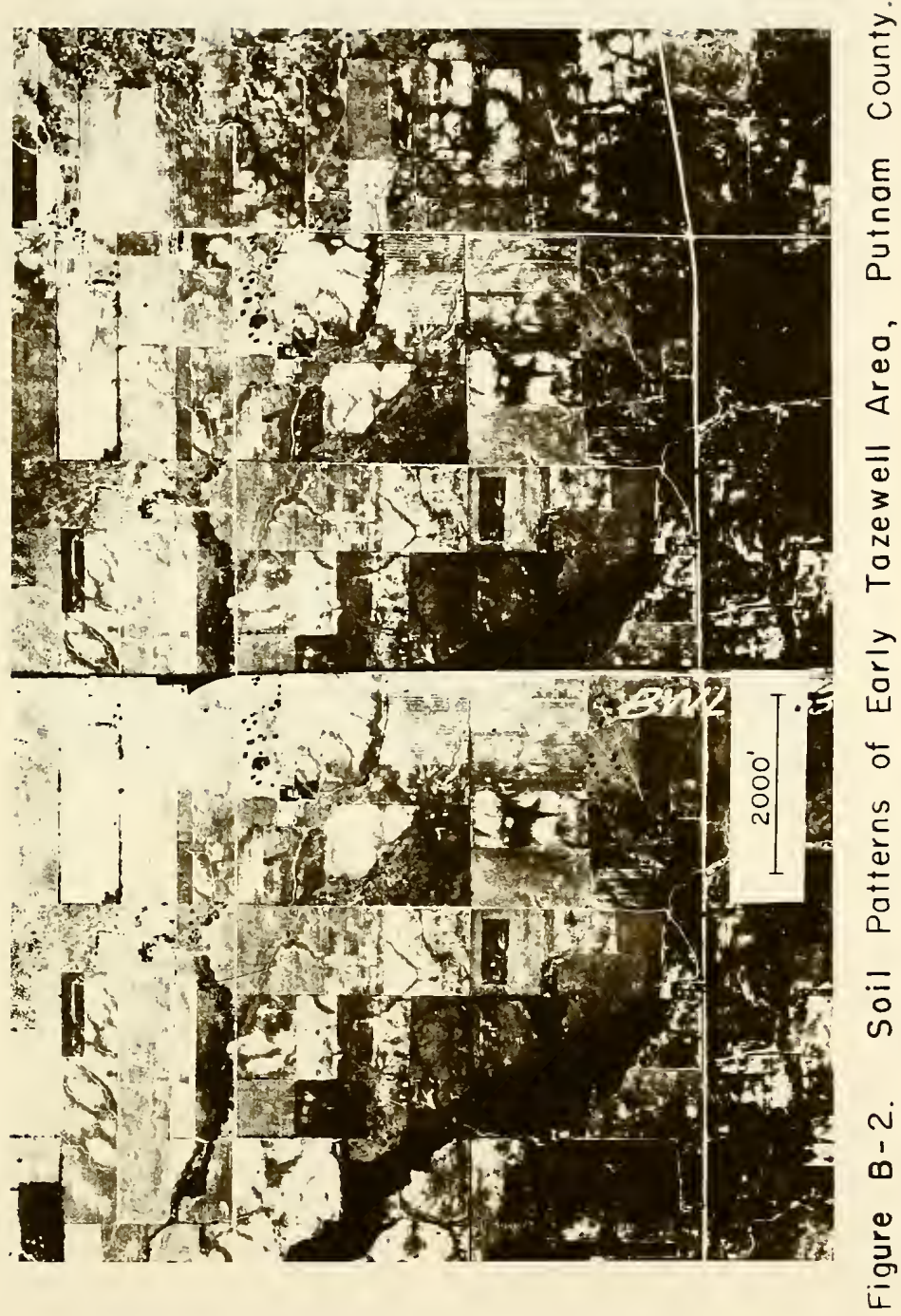




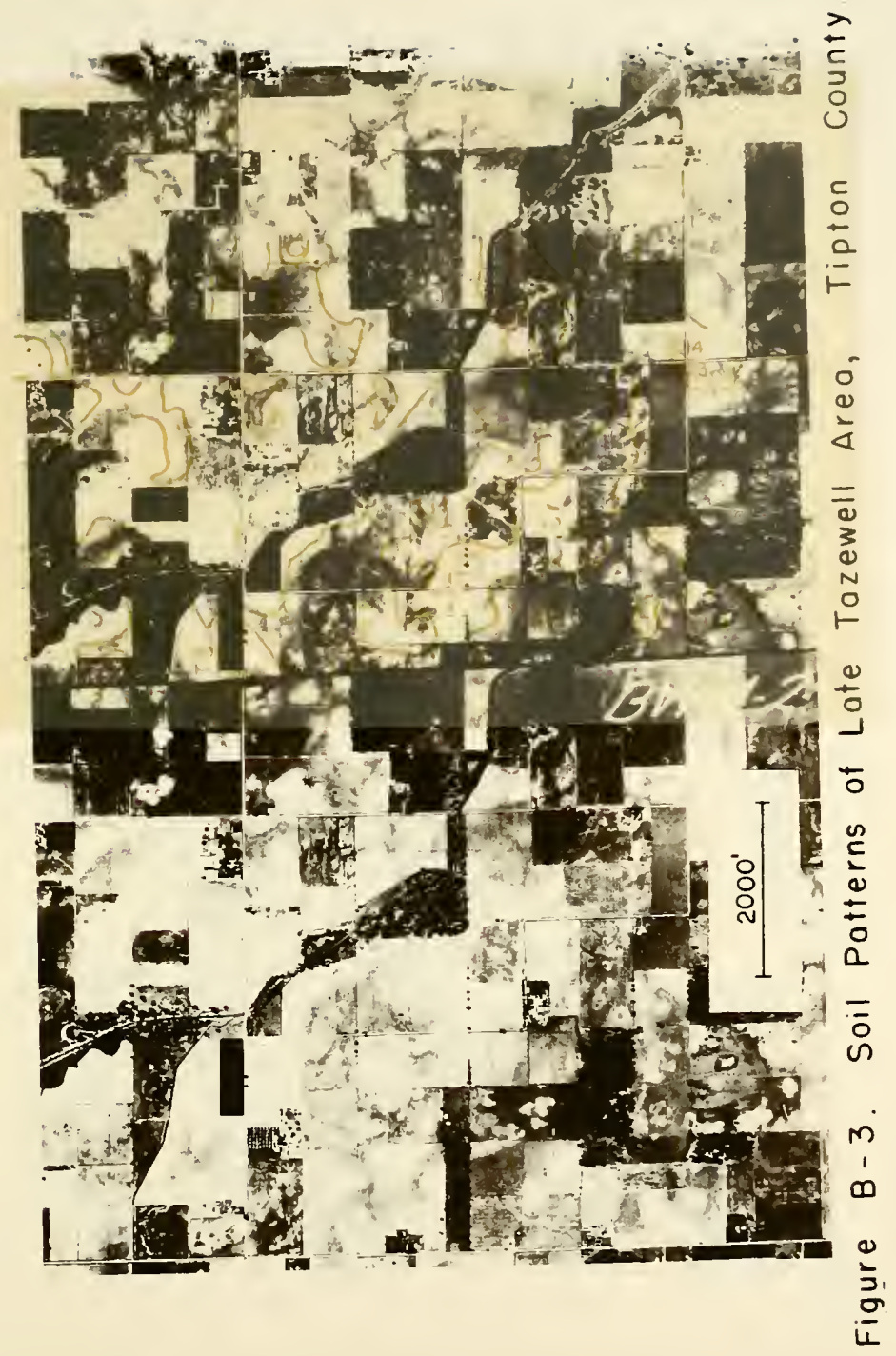




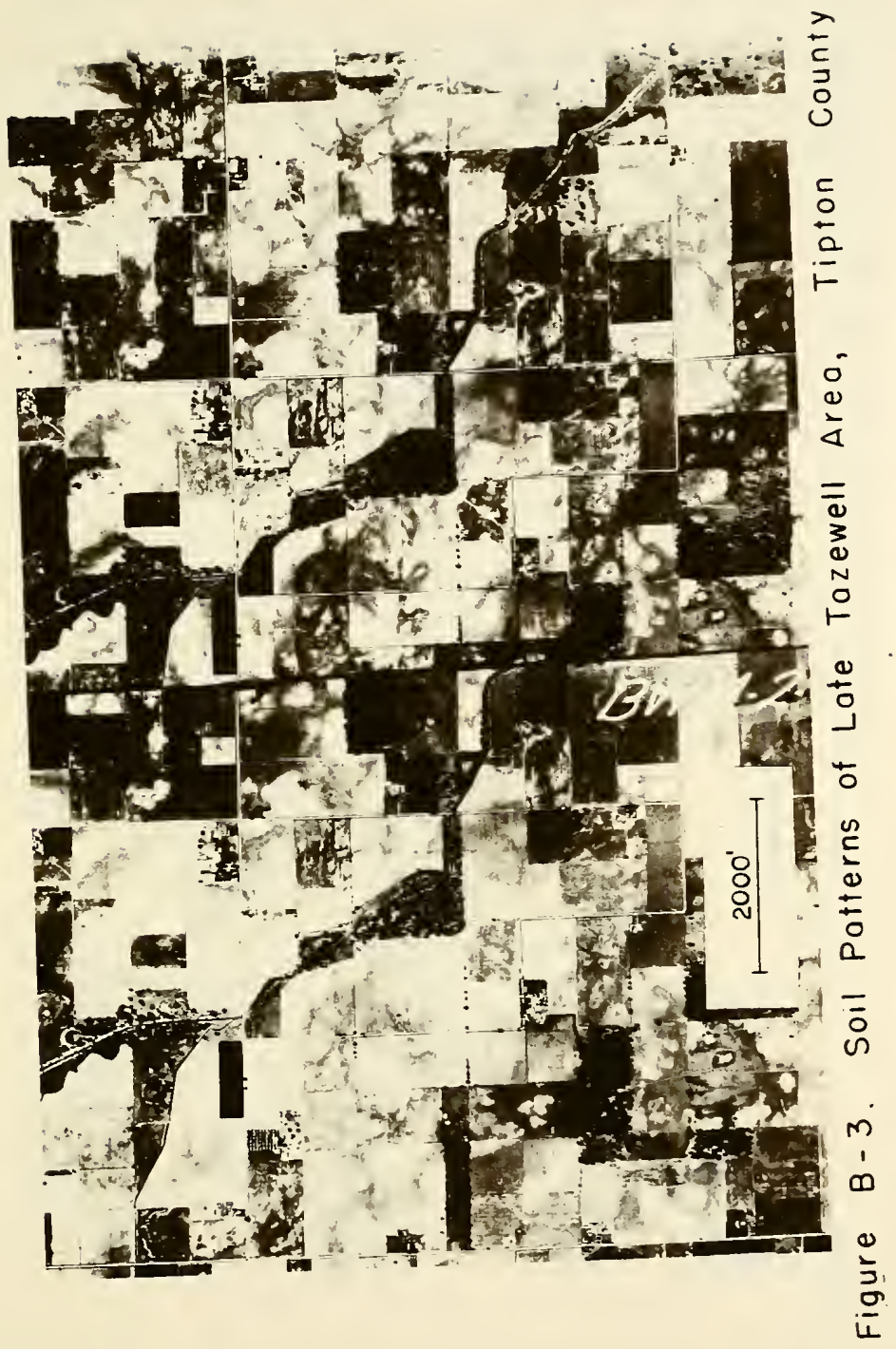




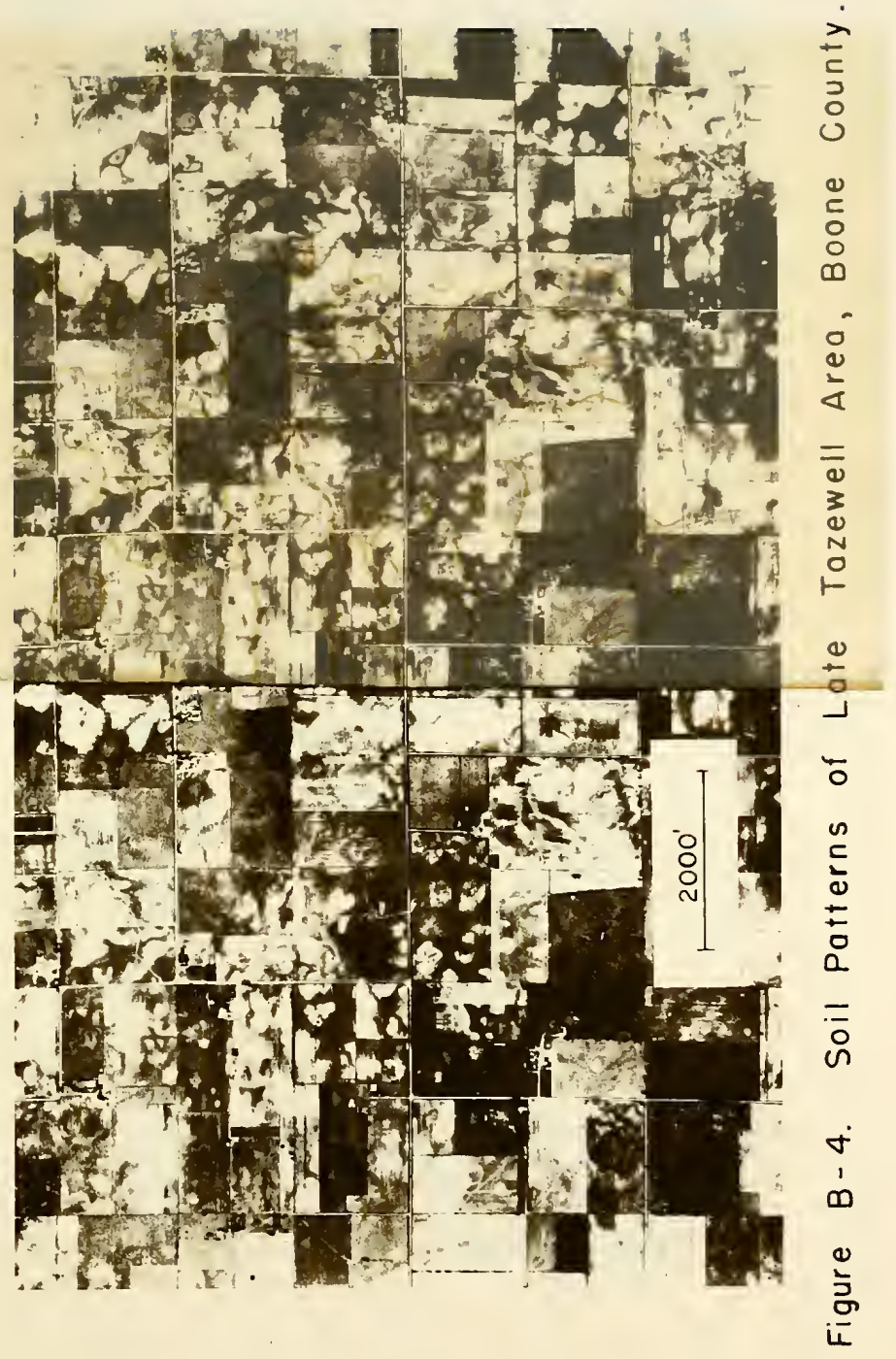




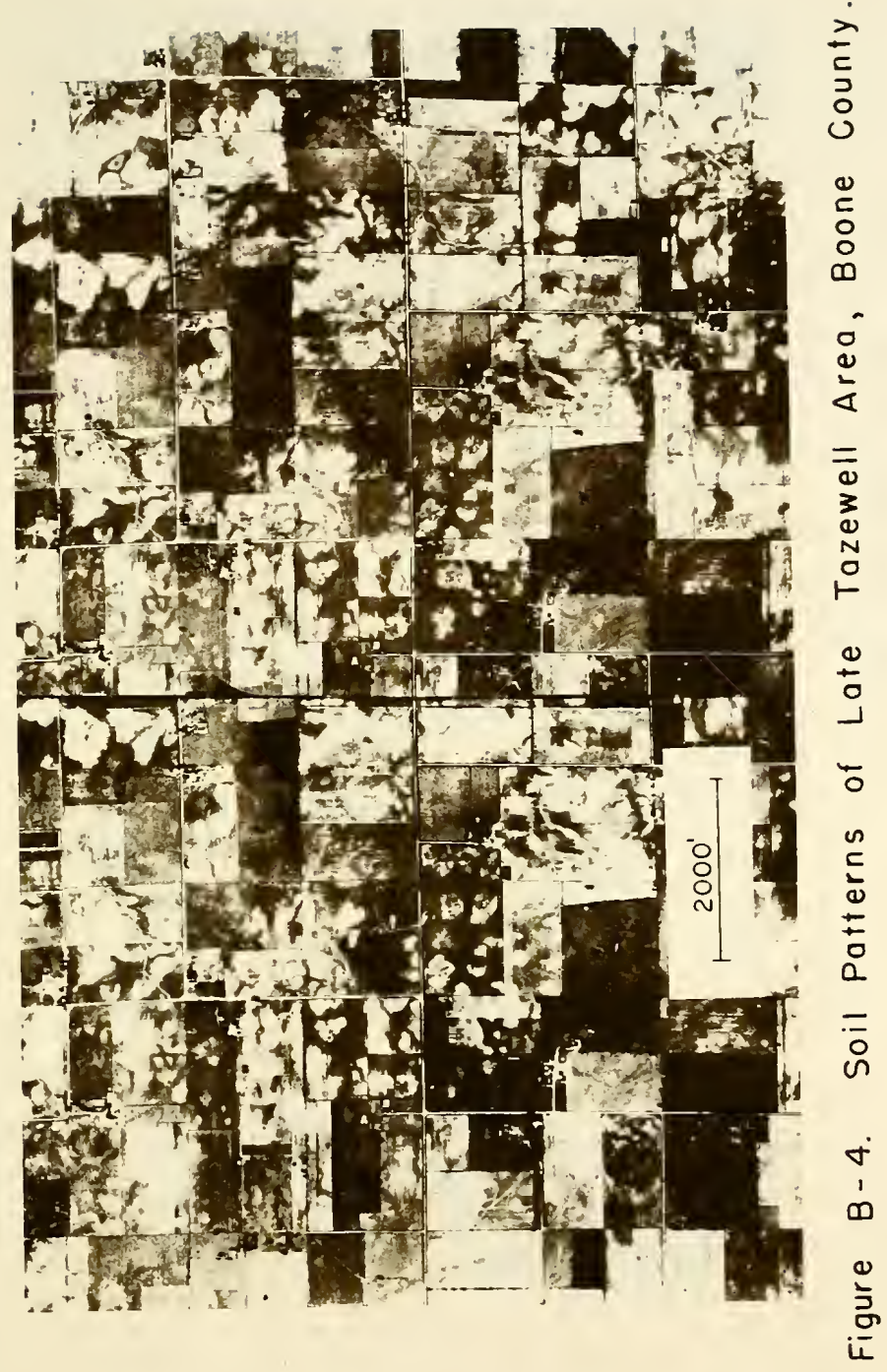




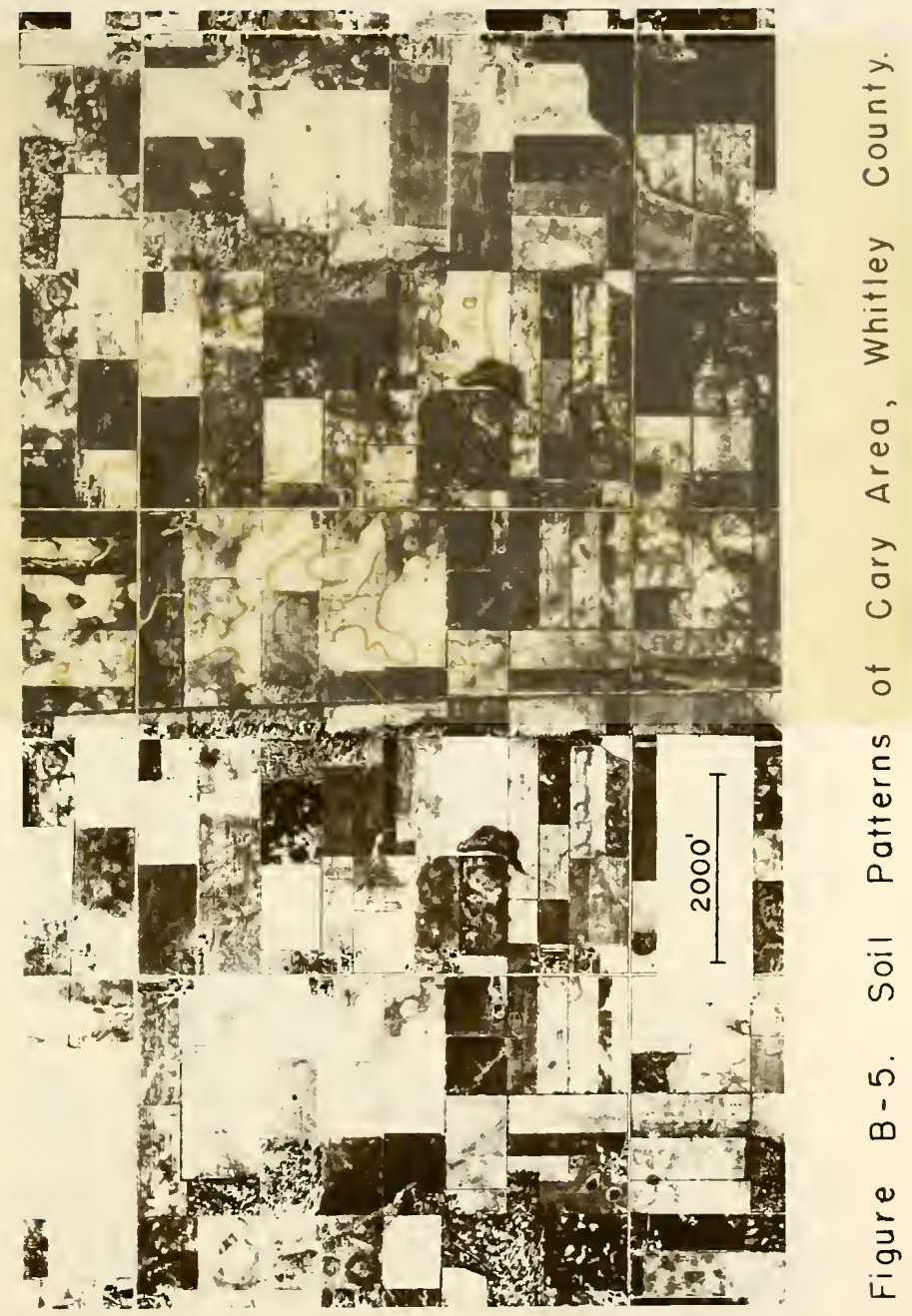




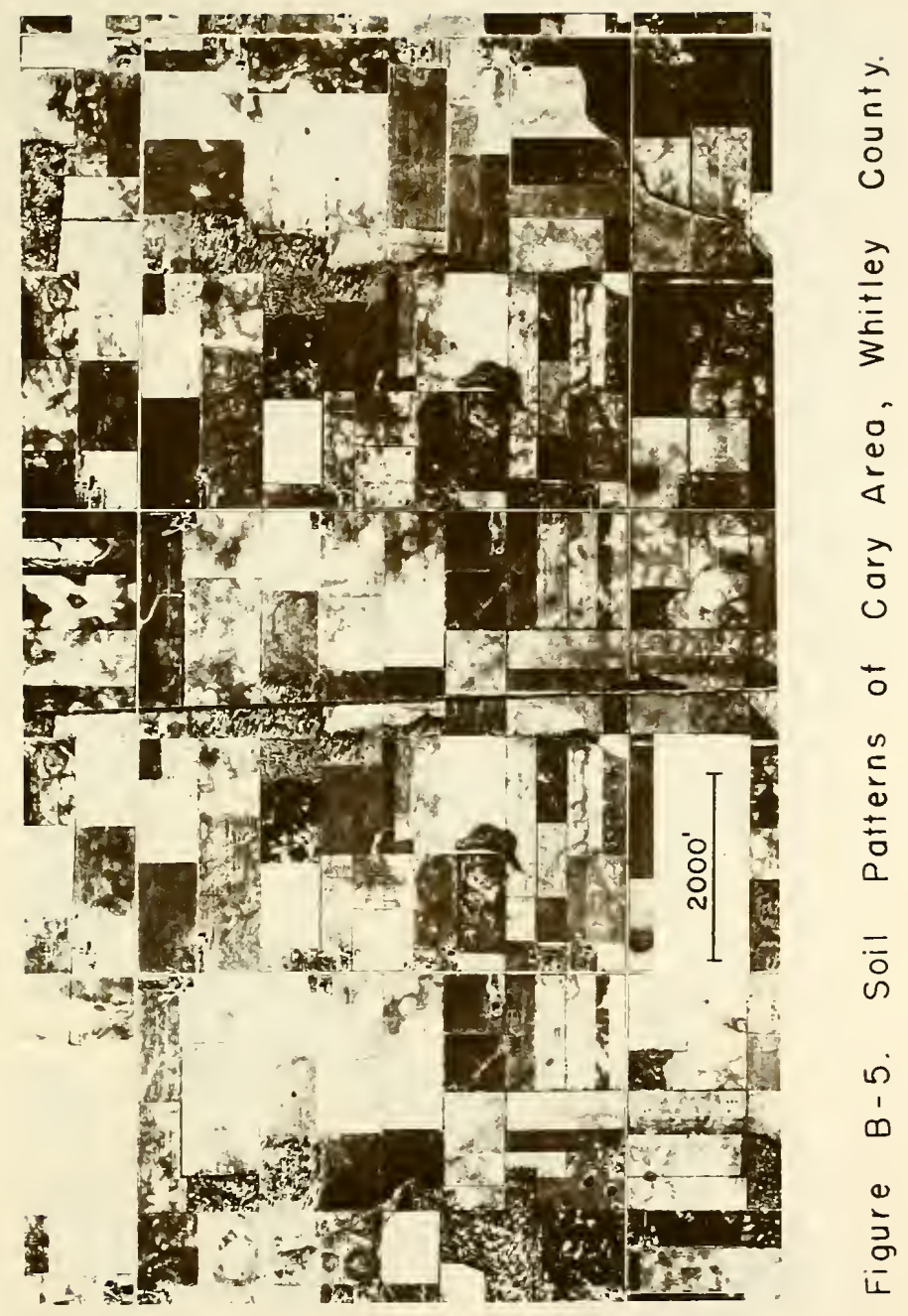




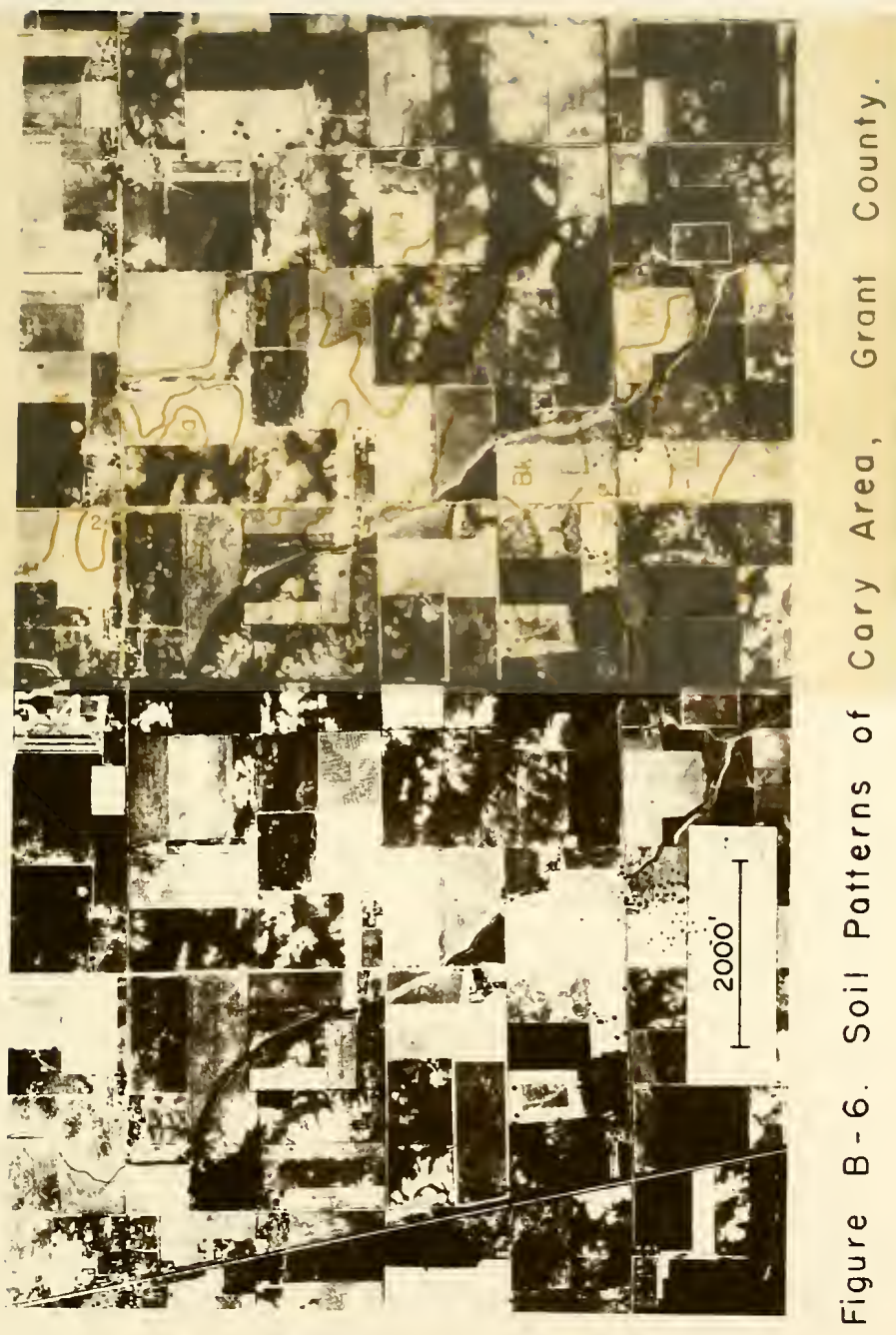




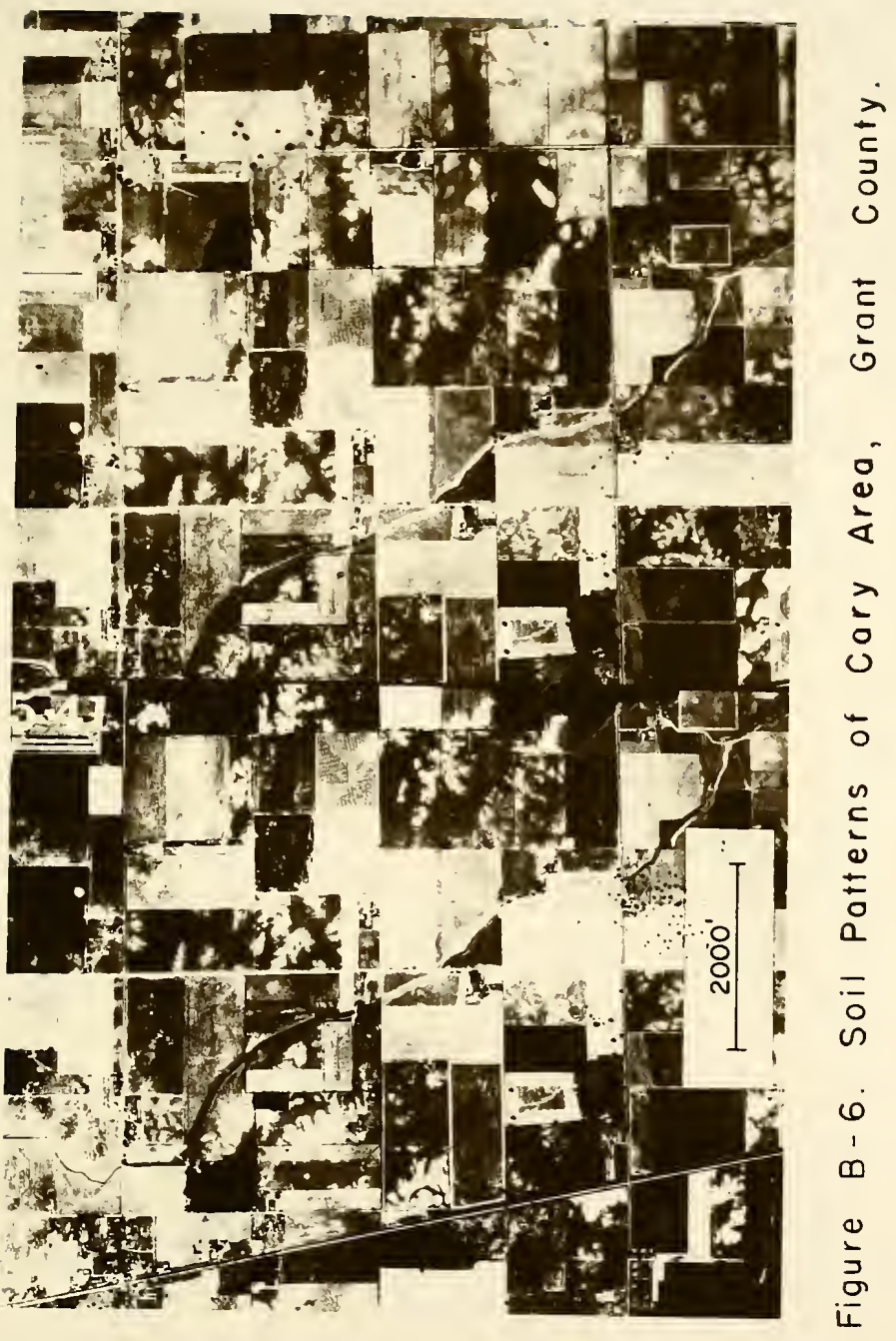


APPENDIX C 


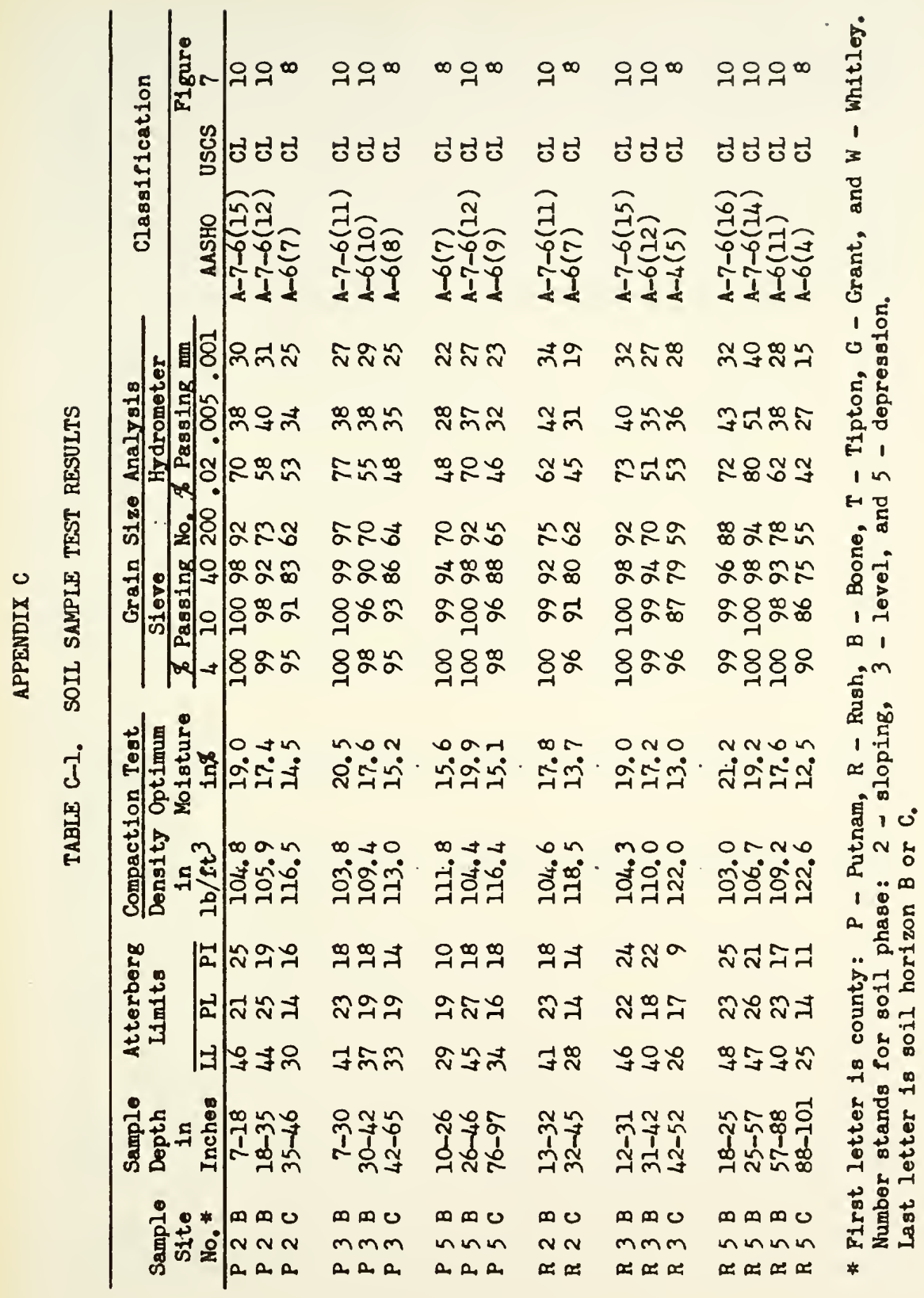




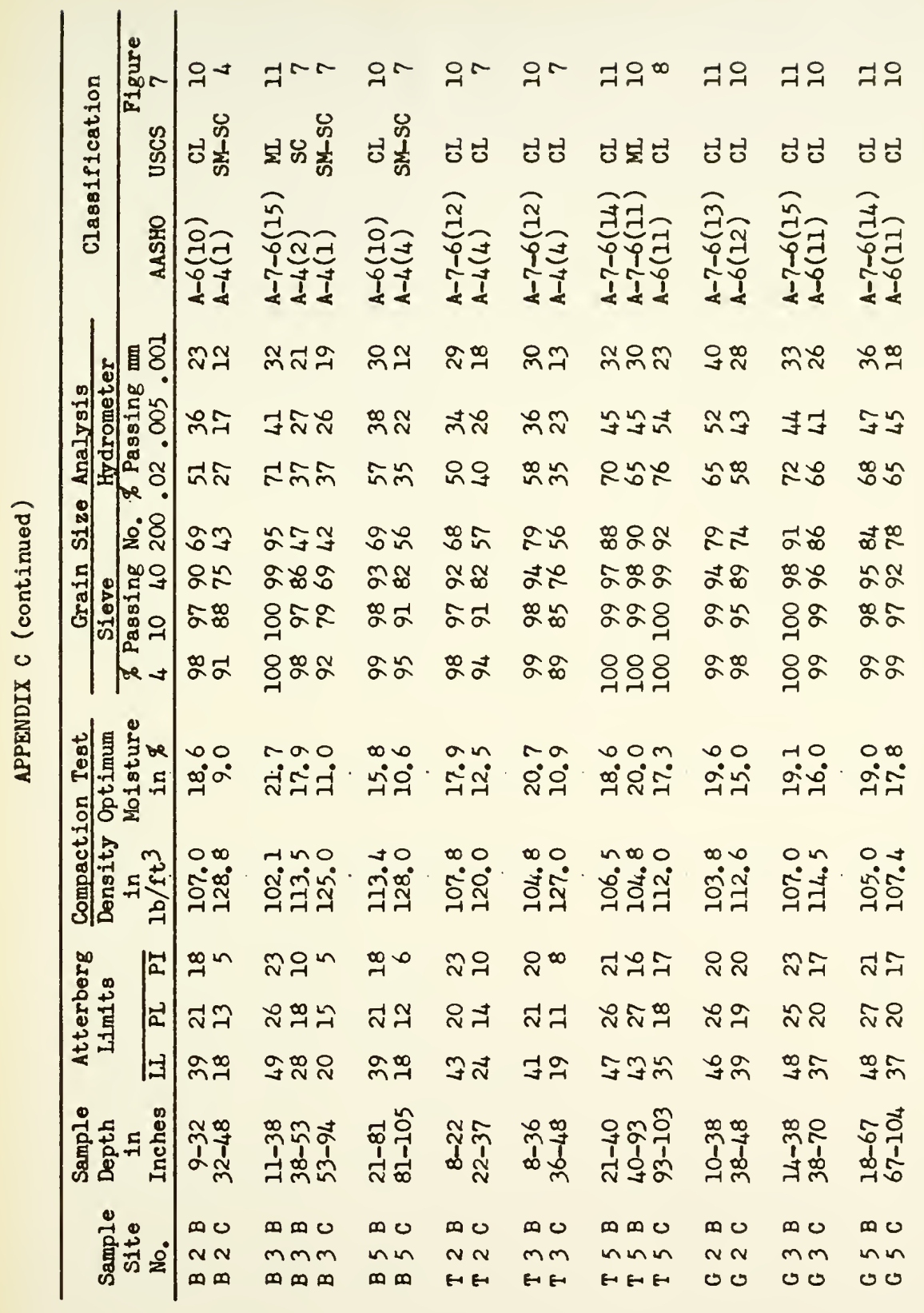




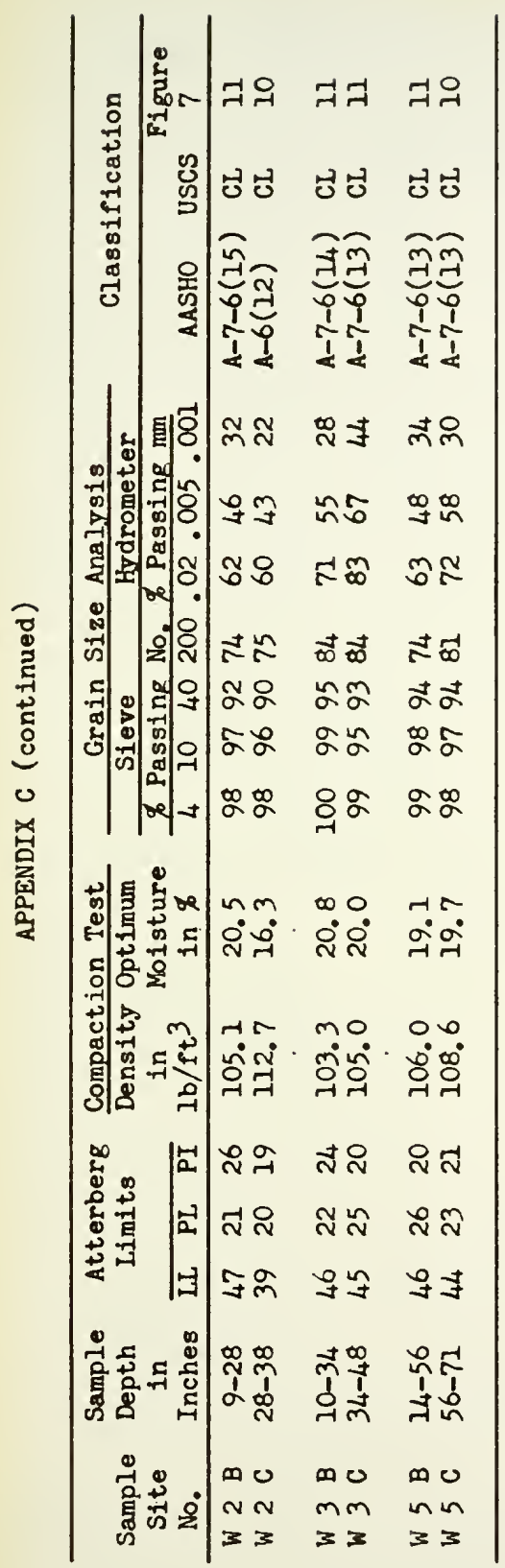



